CUADERNOS DE ESTUDIOS GALLEGOS, LXV Núm. 131 (enero-diciembre 2018), págs. 339-375

ISSN: $0210-847 \mathrm{X}$

https://doi.org/10.3989/ceg.2018.131.12

\title{
REPRESENTACIÓNS DA INFANCIA E IMAXINARIO SOCIAL EN VIDA GALLEGA (1915-1936) \\ E CÉLTIGA (1924-1932). ENTRE O CONFLITO E A NEGOCIACIÓN DE SIGNIFICADOS
}

\author{
María Eugenia Bolaño Amigo \\ Universidade de Santiago de Compostela \\ ORCID iD: http://orcid.org/0000-0002-2436-7144
}

Copyright: (C) 2018 CSIC. La edición electrónica de esta revista se distribuye bajo los términos de una licencia de uso y distribución Creative Commons Reconocimiento 4.0 Internacional (CC BY 4.0).

Cómo citar/Citation: María Eugenia Bolaño AmIGo, "Representacións da infancia e imaxinario social en Vida Gallega (1915-1936) e Céltiga (1924-1932). Entre o conflito e a negociación de significados", Cuadernos de Estudios Gallegos, 65, núm. 131 (2018), págs. 339-375, https:// doi.org/10.3989/ceg.2018.131.12 


\section{REPRESENTACIÓNS DA INFANCIA E IMAXINARIO SOCIAL \\ EN VIDA GALLEGA (1915-1936) E CÉLTIGA (1924-1932). ENTRE O CONFLITO E A NEGOCIACIÓN DE SIGNIFICADOS}

Resumo

Neste artigo pretendemos analizar as diversas representacións da infancia proxectadas a través da revista galega do primeiro terzo do século XX de maior tirada, influenza social e vida máis longa, Vida Gallega (Vigo), e do semanario ilustrado de meirande repercusión entre a emigración galega a América, Céltiga (Bos Aires). A revisión e análise cualitativa de contido da totalidade dos exemplares publicados baixo ambas cabeceiras -no caso de Vida Gallega, un conxunto de 423 números difundidos entre 1915 e 1936; e, se nos referimos a Céltiga, unha totalidade de 182 números editados entre 1924 e 1932-, permite que poidamos achegarnos ao coñecemento das representacións da infancia e do porvir desexado para a sociedade galega enarboradas desde dous medios representativos das realidades galegas de aquén e de alén mar. Palabras clave: Representacións, infancia, imaxinario social, Vida Gallega, Céltiga.

\section{REPRESENTACIONES DE LA INFANCIA E IMAGINARIO SOCIAL EN VIDA GALLEGA (1915-1936) Y CÉLTIGA (1924-1932). ENTRE EL CONFLICTO Y LA NEGOCIACIÓN DE SIGNIFICADOS}

RESUMEN

En este artículo pretendemos analizar las diversas representaciones de la infancia proyectadas a través de la revista gallega de primer tercio del siglo XX de mayor tirada, influencia social y vida más larga, Vida Gallega (Vigo), y del semanario ilustrado con más repercusión entre la emigración gallega a América, Céltiga (Buenos Aires). La revisión y el análisis cualitativo de contenido de la totalidad de los ejemplares publicados bajo ambas cabeceras -en el caso de Vida Gallega, un conjunto de 423 números difundidos entre 1915 y 1936; y, si nos referimos a Céltiga, una totalidad de 182 números editados entre 1924 e 1932-, permite que podamos aproximarnos al conocimiento de las representaciones de la infancia y del porvenir deseado para la sociedad gallega enarboladas desde dos medios representativos de las realidades gallegas de un margen y otro del océano.

Palabras Clave: Representaciones, infancia, imaginario social, Vida Gallega, Céltiga.

\section{REPRESENTATIONS OF CHILDHOOD AND SOCIAL IMAGINARY \\ IN VIDA GALLEGA (1915-1936) AND CÉLTIGA (1924-1932). BETWEEN CONFLICT}

\section{AND THE NEGOTIATION OF MEANINGS}

ABSTRACT

In this paper we intend to analyze the different representations of childhood projected through the Galician magazine of the first third of the 20th century of largest circulation, social influence and longest life, Vida Gallega (Vigo), and the illustrated weekly of greatest impact among Galician migrants to America, Céltiga (Buenos Aires). The review and qualitative analysis of the content of all the copies published under both headings -in the case of Vida Gallega, a set of 423 issues published between 1915 and 1936; and, regarding Céltiga, a total of 182 numbers published between 1924 and 1932-, allow us to perceive how the ideals of childhood and the desired future for Galician society were represented in two relevant media from the Galician communities in both sides of the Atlantic.

KEY WORDS: Representations, childhood, social imaginary, Vida Gallega, Céltiga. 
prensa e, particularmente, as revistas gráficas e culturais logran ampliar o seu campo de divulgación e influenza a comezos do século XX, consolidándose entón como ágoras emblemáticas da vida moderna no espazo cultural europeo. As diversas publicacións periódicas que xermolan neste tempo afírmanse como medios de difusión da produción intelectual e de creación de opinión pública, sobre todo entre os sectores burgueses. Ditos medios de comunicación contribuíron a crear estados de opinión, permitiron ampliar o coñecemento das realidades internacionais, xeraron imaxes de presente e de futuro social, expandiron tendencias ideolóxicas e culturais, e facilitaron un mellor coñecemento dos proxectos sociais e culturais da época. Os voceiros, configurados a partir de multiplicidade de textos e de imaxes, transmitían visións das realidades existentes e desexadas perfilando horizontes para a sociedade a través das súas páxinas. Así acontece no caso galego, onde a prensa escrita por galegos e galegas na emigración de ultramar e a prensa da Galiza territorial adquirirá unha maior relevancia a partir dos anos vinte do pasado século, posibilitando o "achegamento entre as dúas Galizas" do que falou, entre outros, Neira Vilas ${ }^{1}$.

Entre a prensa editada neste tempo na Galiza territorial destaca a revista Vida Gallega (Vigo), por constituír a revista galega do primeiro terzo do século XX de maior tirada, influenza social e vida máis longa; e, entre as publicacións con maior repercusión e forza entre a emigración galega a América, despunta o semanario Céltiga (Bos Aires). A revisión e análise cualitativa de contido dos 423 números publicados entre 1915 e 1936 no caso de Vida Gallega, e dos 182 números editados entre 1924 e 1932 por Céltiga, permite que poidamos indagar nas proxeccións dos segmentos sociais burgueses que reflectían o seu imaxinario social nestes medios, achegándonos ao coñecemento das representacións da infancia e, polo tanto, tamén do porvir desexado para a sociedade galega.

\footnotetext{
1 Xosé Neira Vilas, A prensa galega en Cuba, Sada, Ediciós do Castro, 1985.
} 


\section{A REVISTA ILUSTRADA $V_{I D A}$ GALLEGA}

O primeiro número da revista ilustrada Vida Gallega sae á luz en Vigo no mes de xaneiro de 1909 dirixida por parte do xornalista Jaime Solá, se ben podemos aludir a unha efémera experiencia previa que, xa no 1904 e de man do propio Solá, levara á edición de catro números baixo a mesma denominación, encamiñados á procura de subscritores na emigración. Segundo as afirmacións de Ribao Fernández ${ }^{2}$ isto aconteceu tras o primeiro intento de edición fracasado e, igualmente, poderiamos deducir que posibelmente Solá constatou que na Galiza territorial non había suficiente mercado para soster a publicación. Non en van, a revista editada en Vigo preséntase como "de lujo"3 pois, contando co prezo de unha peseta por exemplar, resultaba ser aínda máis cara que outras publicacións gráficas de referencia no contexto español.

A publicación que xermola no 1909 faino dispoñendo do respaldo de máis de 14.000 subscritores en América ${ }^{4}$ e, deste modo, boa parte do seu financiamento será posíbel mercé aos apoios da colectividade galega de alén mar. Tamén os seus contidos e obxectivos proxectarán vías de comunicación e divulgación entre ambas marxes do Atlántico. Nestes contidos, e incluso a través da abondosa publicidade, pode observarse como se alenta na defensa e propaganda do fenómeno migratorio ${ }^{5}$.

De Vida Gallega publicáronse 779 números entre 1909 e 1963, de maneira que hoxe podemos considerala a revista de maior tirada e lonxevidade do seu tempo; precisamente, é moi destacábel o feito de ter gozado de continuidade durante case trinta anos -ata o mes de marzo de $1938^{6}$-. O subtítulo: "ilustración regional”, dá boa idea daquilo que acontece nas súas páxinas e, xa no primeiro número, expresa a intención de ilustrar con imaxes a vida galega.

Ideoloxicamente podemos aludir á revista como rexionalista, e existen controversias á hora de definila como galeguista. Neste sentido podemos salientar a

\footnotetext{
2 Roberto Ribao Fernández, A fotografia na revista Vida Gallega: un silandeiro universo de sentido, Universidade de Santiago de Compostela, Servizo de Publicacións e Intercambio Científico, 2007.

3 Deste modo pode apreciarse en Las bellezas de Galicia. En Vida Gallega, 75 (15 de setembro de 1916), páx. 12.

4 Así se explicita no primeiro número da revista: “A esos buenos gallegos (emigrantes en América) les debemos gratitud eterna. Si ellos no hubiesen respondido a nuestro llamamiento, Vida Gallega no se habría publicado" -Como nació Vida Gallega. En Vida Gallega, 1 (xaneiro de 1909), cit. en R. RiBao FernáNDEZ, A fotografia..., páx. 356-.

5 Concordamos, a partir das evidencias que amosan as páxinas da revista, coa afirmación efectuada por Rosa María GonzÁlez Bello, “A revista Vida Gallega: unha visión da emigración galega a América (1909-1938)", en Actas do V Congreso Internacional de Estudos Galegos, Sada, Ediciós do Castro, 1999, páxs. 353-363: "Vida Gallega será unha plataforma propagandística do fenómeno migratorio dende unha posición de defensa e mesmo de obvio fomento do mesmo".

6 Posteriormente contará con dúas novas etapas: a primeira, iniciada no ano 1954 contando con José Iglesias Presa como propietario, quen traslada a sede da revista de Vigo a Lugo; e a segunda, desde o mes de maio de 1962, cando é adquirida por parte da empresa editora do Faro de Vigo.
} 
afirmación de Beramendi7 ao definir a revista como "rexionalista ortodoxa"; e, por outra parte, as argumentacións de Marcos Valcárcel ${ }^{8}$ ao expresar o seguinte:

\begin{abstract}
Vida Gallega non era unha revista encadrábel no mundo cultural galeguista aínda que contase nesa época con algunhas firmas ocasionais vinculadas a este movemento ou aínda reproducindo con frecuencia, como facían tantos medios, versos dos clásicos galegos do Rexurdimento. Máis ben habería que dicir que o galeguismo consideraba esta publicación como unha revista de carácter folclórico, dirixida á emigración e a certas capas burguesas hostís aos ideais galeguistas.
\end{abstract}

A lingua empregada na revista é o español, se ben o galego aparece utilizado en poemas, certos textos de narrativa ou outros escritos de tipo lírico. En xeral, concordamos con Molina Sánchez ${ }^{9}$ ao afirmar que o galego aparece na revista concibido como "lingua dos labregos", en certa medida "respectado" pero non contemplado como vehículo de comunicación en substitución do español (agás en casos puntuais, por parte de certos autores concienciados a este respecto); ao que aínda poderiamos engadir a reclusión da lingua galega na revista a textos ou ao acompañamento de imaxes de cariz folclorista.

A cuestión lingüística entronca coas diversas polémicas que se poden apreciar no decurso da publicación, entre as que Molina Sánchez ${ }^{10}$ salienta as vividas cos galeguistas e coa Real Academia Galega, afirmando que durante a primeira etapa da revista mantivéronse inmellorábeis relacións con todos os escritores e artistas galegos ${ }^{11}$ pero as diferentes posicións de apoio ao monolingüismo en galego ou ao bilingüismo (que, con prevalencia do castelán, se consagra como lingua predominante na revista), provocaron a primeira grande disensión entre a publicación e un amplo abano de escritores nacionalistas galegos.

Cun formato menor ao prototípico das revistas ilustradas de tradición decimonónica (31 x $22 \mathrm{~cm}$.), mais superior ao da meirande parte das revistas artísticas e literarias do seu tempo, Vida Gallega era distribuída por Galiza, Portugal, diversas cidades de América e incluso nos transatlánticos que ancoraban no porto de Vigo.

\footnotetext{
7 Justo Beramend, De provincia a nación. Historia do galeguismo politico, Vigo, Xerais, 2007.

8 Marcos VAlCÁRCEL, cit. en Henrique Alvarellos, Un século de Vida Gallega, a revista literaria máis popular, dispoñíbel en http://www.aelg.org/resources/centrodoc/members/paratexts/pdfs/autor317/PT_ [Consulta: 20/10/2017].

9 César Antonio Molina SÁnchez, Prensa literaria en Galicia (1809-1920), Vigo, Xerais, 1989.

${ }^{10}$ C. A. Molina SÁnchez, Prensa literaria ..., páx. 212.

11 Entre outros, Antón Vilar Ponte, José Redomil ou Manuel Barret Fontenla.
} 
A súa periodicidade é inicialmente mensual e quincenal (entre os anos 1909 e 1925), pero con posterioridade esta variará, chegando a ser trimestral e tornándose máis irregular. Tamén, en canto aos contidos e á súa estruturación formal, non resulta unha revista homoxénea no tempo, se ben mantén algunhas constantes formais, tales como unha portada que alterna fotografías con debuxos costumistas ou viñetas de humor gráfico. Cunha concepción temática moderna para a época, mestura información e crónicas de actualidade -sucesos, política ou economíacon outros contidos variados -vida social, emigración, tradicións, literatura, arte, entre outras cuestións- e unha publicidade moi abondosa. É tamén moi ampla a presenza da imaxe e da fotografía, empregada como elemento informativo.

Entre os ilustradores e debuxantes da revista destacan Castelao (que deseñou a portada do primeiro número, así como outras seis portadas durante o ano 1909), Carlos Maside, Álvaro Cebreiro, Ventura Requejo, Eduardo Padín ou Xaime Prada. Ademais dos múltiples artigos asinados por Solá, publícanse esporádicas colaboracións de nomes como Ramón Cabanillas, Noriega Varela, Emilia Pardo Bazán, Manuel Murguía, Tettamancy, Pérez Lugín, Carré Aldao ou Ramón Otero Pedrayo. Ocupan amplo espazo na revista, ademais da publicidade, os contos e os fragmentos de novelas de carácter costumista. Nas páxinas centrais da publicación, de papel satinado, preséntase a crónica gráfica, obra dos máis recoñecidos fotógrafos da época como José Gil, Luis Casado (Ksado) ou Pacheco.

\section{A INFANCIA REPRESENTADA EN VIDA GALLEGA}

Atopamos nas páxinas da revista ilustrada representacións da infancia e da súa educación que son maioritariamente presentadas a través de fotografías, viñetas e, en menor medida, textos literarios e informativos. A infancia aparece retratada en Vida Gallega como a etapa vital da inocencia e da inxenuidade, que poderá ser "superada" mediante unha educación moral impartida nos centros escolares e por parte de "mestres exemplares". Con todo, as representacións infantís que se ofrecen adoitan estar ligadas a realidades sociais ben diferentes (remitindo aos diversos contextos de pertenza e extracción social), entre elas podemos distinguir: a "infancia campesiña e mariñeira", que adoita asociarse ao mundo rural galego de aquén mar; a "infancia desvalida" (habitualmente orfa e abandonada) e, polo tanto, necesitada de "protección"; ou ben a "infancia de ben", vencellada aos segmentos sociais acomodados, fundamentalmente do territorio da emigración.

Estas representacións que distinguimos e ás que se asignan roles ben diferentes ocupan espazos diversos nas páxinas de Vida Gallega, adquirindo maior ou menor magnitude e relevancia en relación aos soportes nos que son presentadas. Así, a "infancia rural” adoita aparecer representada a través das viñetas gráficas (habitualmente con pé de texto) e dos poemas; a "infancia desvalida", nas cróni- 
Gráfico 1. Relación entre a totalidade de páxinas consultadas e as extraídas para o estudo das representacións en Vida Gallega

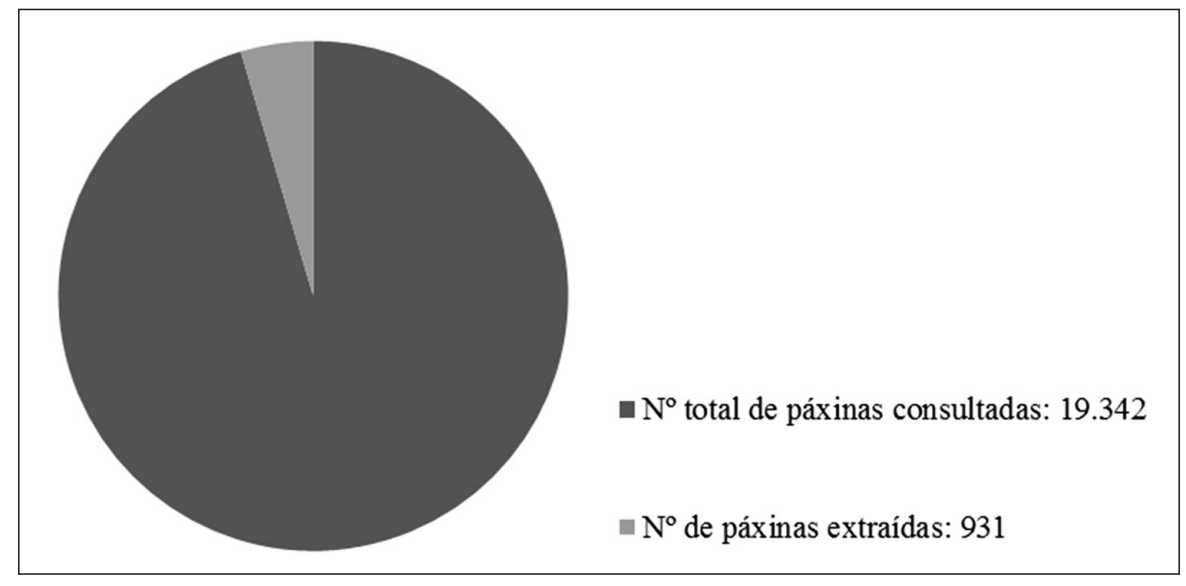

Fonte: elaboración propia.

cas informativas textuais ou ben nas crónicas gráficas, onde gaña presenza a protección favorecida mediante a caridade e a filantropía; e a "infancia de ben", fundamentalmente presente nas fotografías individuais e grupais. Esta diverxencia, e tendo en conta que Vida Gallega outorga preeminencia á linguaxe fotográfica, semella seguir unha lóxica que cede protagonismo a unha "infancia desexábel", como aquela infancia ligada aos segmentos sociais de estatus elevado, relegando a un plano secundario, case nostálxico e sentimental, á infancia pertencente ao mundo rural. A isto engádese o cariz folclorista cando esa pertenza rural se sitúa no territorio galego.

As representacións da infancia que atopamos na revista, aínda que cualitativamente destacábeis, non son cuantitativamente abondosas. Mostra disto é a porcentaxe que ocupan as páxinas que extraemos para a análise das representacións fronte á totalidade das páxinas consultadas en Vida Gallega: o 5 por cento. Isto pode levarnos a aludir aos "silencios" con respecto ás representacións da infancia (e/ou dos seus testemuños) na revista, mais neste caso valoramos que na publicación son moitas as páxinas íntegras destinadas á publicidade e á presentación de imaxes a páxina completa -aspecto que ten repercusións nas cifras e porcentaxes que amosamos-.

En canto á evolución das presenzas e ausencias da infancia, da adolescencia e da súa educación nas páxinas da publicación, observamos que, agás no caso do ano 1916, apréciase en Vida Gallega o incremento das imaxes e textos destinados a esta cuestión a medida que pasan os anos. A tendencia acentúase entre o 1926 e 
Gráfico 2. Páxinas extraídas para o estudo das representacións (por ano) en Vida Gallega

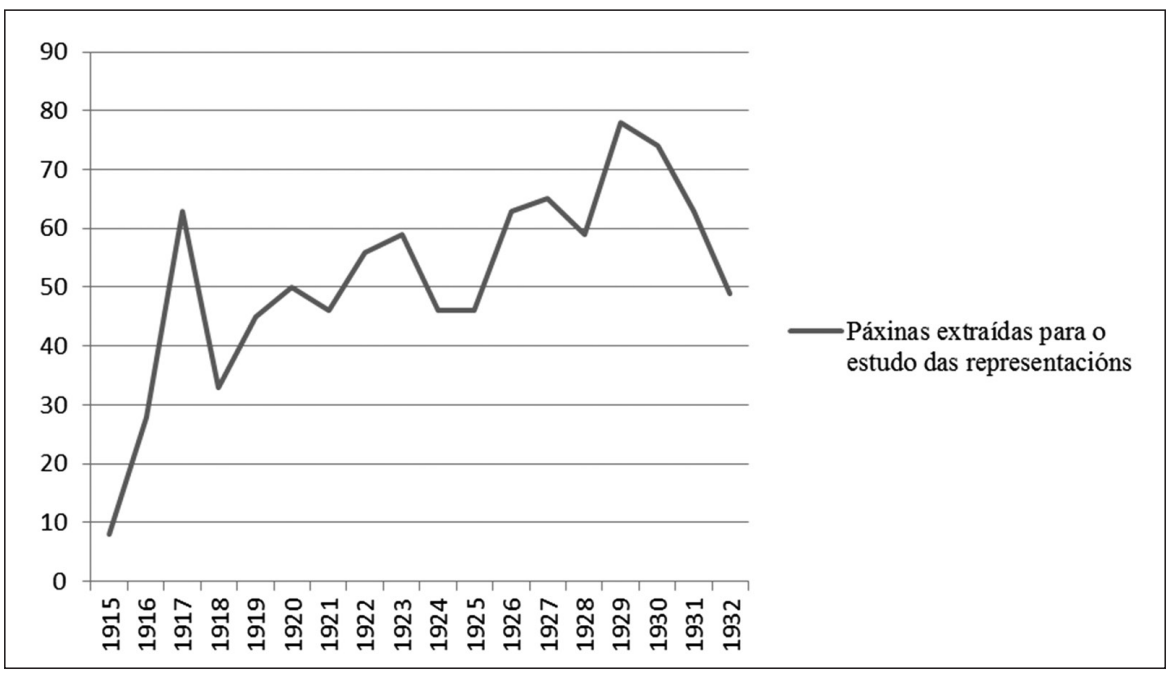

Fonte: elaboración propia.

o 1931, correspondéndose o ano 1929 co maior número de documentos extraídos, e sendo no 1930 cando máis portadas abordan temas relacionados coa infancia, a adolescencia e/ou a súa educación (sumando unha totalidade de trece portadas).

Destaca en Vida Gallega o notábel protagonismo outorgado á escola e, aínda máis concretamente, aos edificios e aos espazos escolares, tanto a través da imaxe fotográfica como dos textos. As escolas adoitan ser concibidas na revista como centros para camiñar cara o "progreso"; un percorrido posibilitado por parte de mestres "modélicos" que teñen como finalidade primordial "elevar os valores morais" para "forxar homes cultos".

Por outra parte, entre a publicidade son moi numerosos os anuncios destinados á hixiene e á saúde, ocupando un lugar salientábel a propaganda de medicamentos para nenos e nenas, habitualmente dirixida ás nais como "responsábeis" dos coidados.

Podemos salientar en Vida Gallega os seguintes tópicos:

I) Infancia inocente, inxenua e algareira. Viñetas que reflicten a realidade social desde a picaresca infantil

Atopamos reproducidas en Vida Gallega moi numerosas viñetas de humor gráfico con autorías varias (como as propias de Castelao, Ventura Requejo, Xaime Prada, Maside ou Eduardo Padín, entre outros). Nestas estampas, que aparecen 


\section{INXENUIDADE Por Jaime Prada}

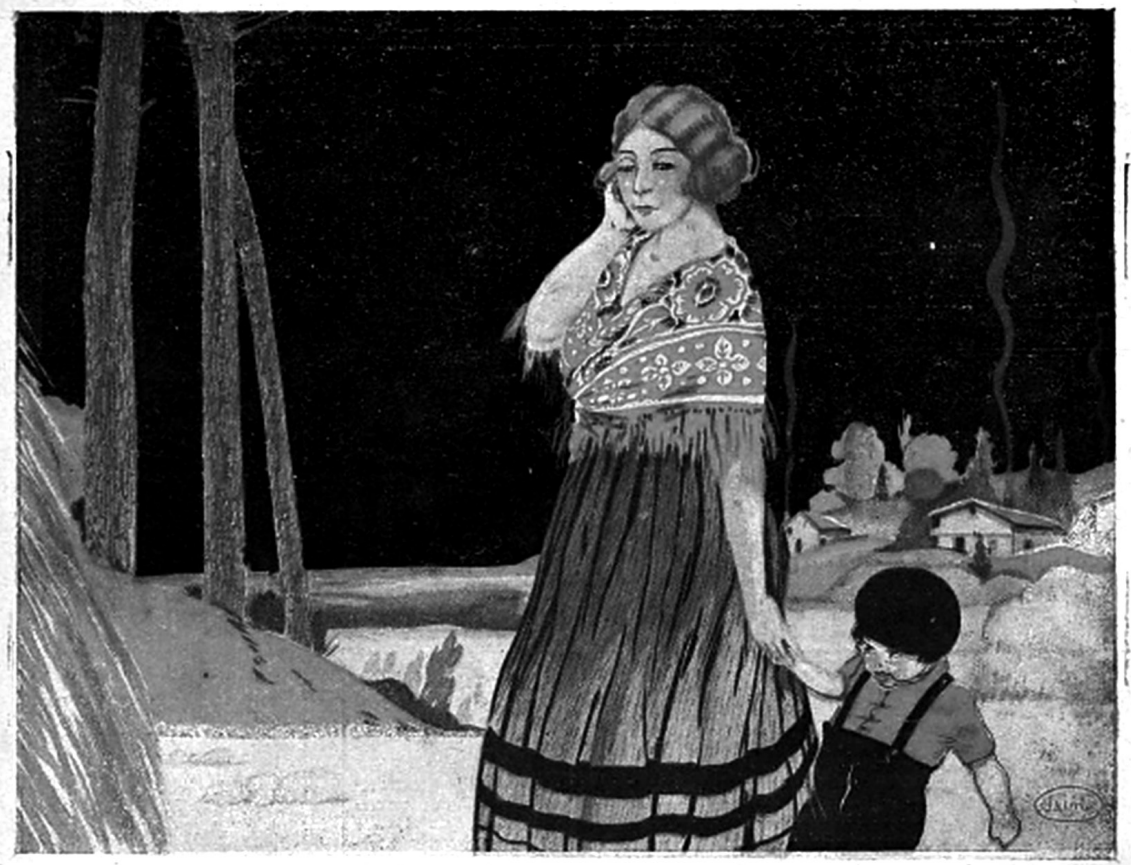

- Na nai; eu reño medo as bruxas

- ¿Bruxas? Non-as hai, fillo.

-E enton - diga vosté que o sabe - ¿qué é a nai de papai....?

Fig. 1. Inxenuidade, por Jaime Prada. En Vida Gallega, 15 de febrero de 1922, núm. 190, páx. 1.

habitualmente situadas nas portadas dos números da revista e noutras páxinas relevantes, adoitan expresarse as xentes do común que, mediante o sarcasmo, a ironía ou a retranca, reflexionan, conversan ou protestan en prol das vivencias do pobo, en contra das opresións exercidas por parte de caciques e dunha parte dos sectores economicamente acomodados. Así, nestas imaxes con pé de texto, dignifícase a Galiza popular e as súas xentes a través das preguntas retóricas, os consellos, as queixas ou os diálogos colmados de crítica social ${ }^{12}$.

\footnotetext{
$\overline{12}$ No caso das viñetas ás que aludimos valoramos que adoita sobrepoñerse a crítica social dos autores das mesmas ao ton que, xeralmente máis conservador, predomina na revista. Desde esta perspectiva podemos remitir aos traballos que elaboramos en torno ás representacións da infancia na obra de Castelao: Antón Costa Rico e María Eugenia Bolaño Amigo, "Castelao: nenos, sociedade e educación. Denuncia e patria soñada na Galiza dos anos vinte", en Imatges de l'escola. Imatge de l'Educació. Actes de les XXI Jornades d'Història de l'Educació, Palma de Mallorca, Universitat de les Illes Balears, 2014, páxs. 297-311; María Eugenia Bolaño Amigo, "Os nenos en Castelao", en Gran Enciclopedia Galega, A Coruña, Novos Vieiros, 2015, tomo 49, páxs. 166-173.
} 
As nenas e os nenos, caracterizados como seres inocentes, inxenuos e/ou algareiros, adoitan aparecer como protagonistas destas viñetas que dan conta da realidade social galega. As súas verbas son sinxelas e breves, mais a capacidade de expresión que nelas radica é ampla e sincera. As viñetas extraídas para a análise, que constitúen unha totalidade de trinta e cinco, caracterízanse por remitir tematicamente á vida comunitaria no rural galego. As temáticas que nelas acostuman ser abordadas, de maneira máis ou menos explícita, fan referencia a situacións de pobreza e de precariedade no seo familiar (remitindo habitualmente á fame e a outro tipo de carencias); a problemáticas ligadas ás relacións intra e interfamiliares (parentesco); á cuestión da minorización lingüística galega; críticas á política caciquil; e, en menor medida, críticas á pedagoxía escolar e aos métodos empregados por parte de mestres e escolantes.

II) Infancia emigrante: futura "gente de bien".

Existe nas páxinas da revista Vida Gallega unha visión positiva da emigración que tamén se traslada ao aludir ás crianzas que emigran e á súa formación, así como ás desexábeis finalidades dos propios procesos formativos. En relación á defensa do éxodo cara o outro lado do Atlántico efectuada, con diversos matices, ao longo de toda a existencia da publicación, ten expresado Rosa M. González Bello ${ }^{13}$, o seguinte:

Vida Gallega (...) non só o vai xustificar, senón que o propiciará a través dunha visión positiva, convenientemente edulcorada, de todo o proceso migratorio dende a viaxe ata a vida cotiá e laboral dos galegos en América. Manterá esta visión mesmo a pesar das múltiples voces que nestes anos, e sobre todo dende sectores próximos ao galeguismo, se alzan para cuestionar os efectos traumáticos do éxodo.

Os apoios á emigración sostidos na revista non son fortuítos, pois o éxodo constituía entón:

un grande sector activador da economía dun certo sector da burguesía vinculado ás grandes compañias internacionais de vapores que con tanta profusión e intensidade se publicitarán na revista durante

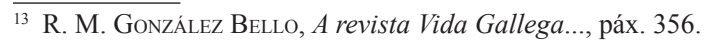


toda a súa existencia. Dende o primeiro número de Vida Gallega constatarase a defensa dos intereses das empresas navieiras, e indirectamente das grandes casas consignatarias de Vigo e A Coruña ${ }^{14}$.

Non en van, aparecen publicadas -sobre todo nos primeiros números da revista-numerosas reportaxes sobre os máis recoñecidos buques que ancoraban a ambas marxes do océano. Estas reportaxes, de carácter publicitario e apoiadas polas propias compañías, contribuían a fornecer unha visión practicamente idílica das condicións das viaxes ${ }^{15} \mathrm{e}$ dos contextos de chegada, onde a emigración é presentada "como un fenómeno vinculado a un triunfo case inexcusable, reforzando esa idea do esforzo persoal coroado polo éxito a través de glosas reiteradas sobre traxectorias individuais con final feliz"16. Perspectivas favorecidas posibelmente polos importantes ingresos que supoñía esta publicidade para a revista ${ }^{17}$, e aínda polos convites das navieiras aos redactores de Vida Gallega para a realización de viaxes promocionais.

Polo mesmo, os suxeitos infantís que emigran (maioritariamente nenos), son representados como futura "gente de bien", facendo fincapé no éxito do seu porvir no estranxeiro. Estas representacións compleméntanse coa presenza de seccións como Nuestros hombres en América, que concede transcendencia a persoeiros que lograron unha folgada posición económica en Arxentina, Cuba, Uruguai ou Brasil; e outros textos onde se ofrece unha imaxe dos indianos que fixeron capital en América "como os grandes dinamizadores da economía galega e impulsores do desenvolvemento industrial e comercial"18. Lígase así a prosperidade alén mar co progreso económico na Galiza territorial, salientando os beneficios tanto dos investimentos dos indianos enriquecidos, como das remesas de diñeiro enviadas por traballadores galegos emigrados.

Con todo, a través das viñetas de humor gráfico a ollada respecto da emigración resulta máis plural e crítica (en harmonía cos idearios das respectivas autorías). Boa mostra disto pode ser a viñeta Os pescadores de Cebreiro, onde o diálogo entre dous homes de avanzada idade e ollar melancólico expresa:

\footnotetext{
$\overline{14}$ M. González Bello, A revista Vida Gallega..., páx. 356.

15 Relatos propagandísticos que adoitaban non ter correspondencia coa realidade.

${ }^{16}$ R. M. GonzÁlez Bello, A revista Vida Gallega..., páx. 357.

17 Afirma R. M. GonzÁlez Bello, A revista Vida Gallega..., páx. 357, que "das oito compañías inglesas, catro alemanas, tres francesas, dúas holandesas e tres españolas que prestaban servizo a principios do século nos portos galegos, a maior parte apareceu repetidamente nas páxinas de Vida Gallega, dende a Lloyd Norte Aleman-Bremen ata a Compañía do Pacífico ou a Hamburguesa Sudamericana”.

${ }^{18}$ R. M. GonzÁlez Bello, A revista Vida Gallega..., páx. 357.
} 
- A min o mar xa me levou tres fillos.

- ¿Afogaron?

- Non, foron prás Américas... ${ }^{19}$.

III) Crianzas pobres, abandonadas e orfas: "problemas resueltos gracias a la caridad bien organizada".

Destínanse en Vida Gallega numerosas páxinas a presentar, fundamentalmente mediante reportaxes fotográficas, unha visión positiva da "caridad bien organizada" 20 . Préstase especial atención nestas reportaxes ás obras "caritativas" desenvolvidas nas cidades de Vigo e de Lugo, aparecendo tamén en menor medida loubanzas a determinadas actuacións efectuadas en Santiago de Compostela e Ourense.

Desde unha visión burguesa, idealízanse na publicación as accións promovidas para paliar, mediante a "organización da caridade", a presenza de "mendicidad callejera" propia dos "desheredados de la fortuna" 21 e "hacer de los antiguos golfos unos niños de provecho" 22 . Así, aparecen variadas referencias ás cantinas escolares para “niños pobres” de Lugo, á cociña económica e á Gota de Leche de Vigo, aos "nuevos asilos de Vigo para niñas desamparadas", ao asilo da infancia de Santiago e ao Asilo Ilundain de Ourense, entre outros.

Ao aludir a estas experiencias, saliéntase o labor das persoas que se sitúan á fronte da Administración, destacando determinados atributos como cando se alude a "D. Fernando Conde, popular y cultísimo alcalde de Vigo, afortunado y tenaz promotor de la organización de la caridad, que resolvió el problema de la mendicidad callejera, suprimiéndola en absoluto"23; ou ao "activísimo (...) [e] infatigable secretario de todas las instituciones benéficas del Ayuntamiento"24.

Nas fotografías destínase especial atención ás infraestruturas das institucións destinadas á "protección" da infancia e da sociedade en xeral, e son menos aquelas nas que aparecen os nenos e as nenas. Neste sentido poderíamos falar dun maior interese cara os espazos e o diñeiro invertido nos mesmos, que en relación ás nenas e nenos e ás súas situacións específicas. En ningún caso se efectúa na revista unha análise que indague nas causas da pobreza, do abandono e da orfandade.

\footnotetext{
$\overline{19 \text { Vida Gallega }} 471$ (30 de decembro de 1930), páx. 1.

20 Así pode apreciarse, a modo de exemplo, en Vida Gallega, 85 (20 de abril de 1917), páx. 18.

21 Vida Gallega, 85 (20 de abril de 1917), páx. 18.

22 Vida Gallega, 125 (10 de maio de 1919), páx. 15.

23 Vida Gallega, 85 (20 de abril de 1917), páx. 18.

24 Vida Gallega, 85 (20 de abril de 1917), páx. 18.
} 

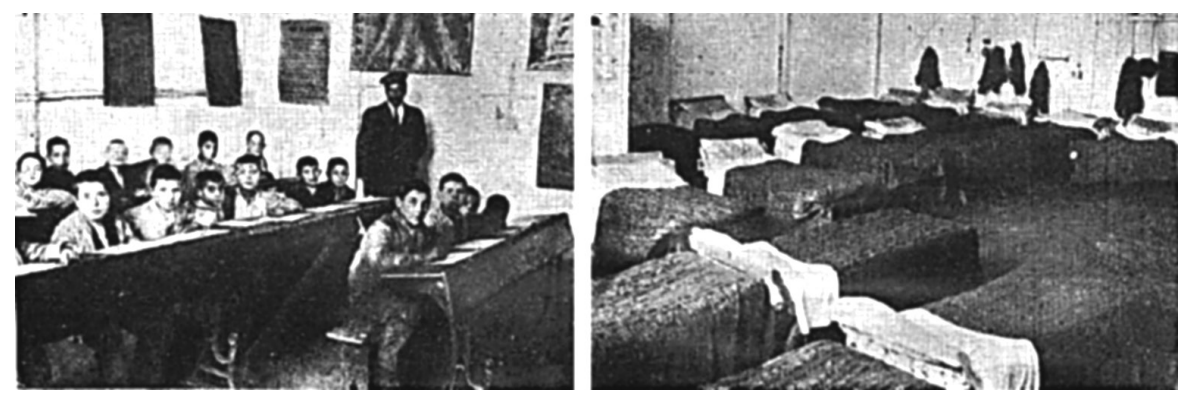

Fig. 2. Fotografias de Asilo, por Jaime Pacheco. En Vida Gallega, 20 de abril de 1917, núm. 85, páx. 18 .

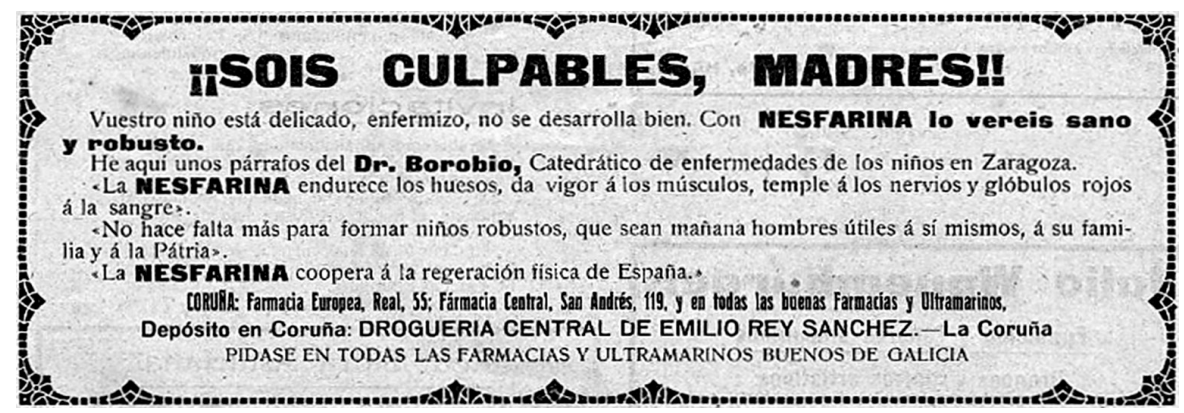

Fig. 3. Publicidade de Nesfarina. En Vida Gallega, 1 de agosto de 1916, núm. 73b, páx. 15.

IV) A saúde infantil e a “culpabilidade” das nais. Protagonistas na publicidade.

A publicidade é moi abondosa en Vida Gallega e, no que a esta se refire, a infancia adoita aparecer representada - a meirande parte das veces xunto coas figuras maternas- nos anuncios ligados ao eido da saúde e dos coidados (fundamentalmente da hixiene).

A propaganda de medicamentos e de reconstituíntes é moi habitual; nela gañan presenza as ideas da importancia e da responsabilidade do coidado materno -ao que se achacan tamén as culpabilidades de todos os males dos nenos e das nenas-, aparecendo habitualmente alusións á elevada mortalidade infantil. Pode apreciarse esta cuestión na imaxe publicitaria que incorporamos deseguido, representativa da propaganda destas características.

A idea de "culpabilidade materna" en relación á saúde dos fillos e fillas está explicitamente evidenciada no anuncio presentado, no que ademais se apela ás características desexábeis nos nenos: "sans e robustos", e "fortes e útiles a si mesmos, á familia e á patria". Así, observamos que o patriotismo aparece tamén na publicidade, como horizonte da "utilidade" das persoas e do seu porvir. 
Relacionada coa idea da "culpabilidade" maternal, aparecen en Vida Gallega tamén os tópicos de "nai mártir", "sufridora", e "sacrificada", pois é sobre ela onde recae o peso dos coidados da familia e do fogar. Estes aspectos adoitan aparecer expresados, e incluso idolatrados (propiciando, así, a súa reproducción) a través de poemas como o texto $A$ mi madre de Enrique Blanco ${ }^{25}$.

V) “Forjadores de hombres cultos": unha educación escolar impartida por "maestros ejemplares".

Debido á importancia da que goza a educación escolar tradicional en Vida Gallega, os mestres son considerados persoas "exemplares" e, nas descricións relacionadas coa súa figura faise fincapé nos aspectos vocacionais para poder "instruír" e traballar "luchando contra la ignorancia"26, no seu talento e na súa "cultura, en el amor a la enseñanza, en la delicadeza del trato social"27.

Son amplas e detalladas as descricións ofrecidas na revista en relación á creación de escolas e á chegada de novos mestres, atendendo particularmente ás súas calidades e virtudes:

En Gomariz se acaba de crear una escuela, y a ella fué destinado un pedagogo que, si no se aficiona a la campiña, andará poco tiempo por las soledades del agro. Se llama este maestro José Gómez López. Es uno de los educadores a la moderna. Muy estudioso, muy culto, muy urbano, muy convencido de la trascendencia de su misión, muy enamorado de su carrera, muy decidido a pelearse, donde quiera que vaya, contra el analfabetismo; muy capacitado, no solo para hacer niños instruidos, sino para forjar hombres cultos ${ }^{28}$.

Neste tipo de descricións, a preparación e "recoñecido renome" dos mestres tamén está presente, e aínda se destaca cando fan da labor pedagóxica "un sacerdocio" 29 . Este labor dos mestres aparece retratado en Vida Gallega en breves interaccións onde o rol autoritario dos docentes se sobrepón aos intereses do alumnado ao berrar: “¡Pronto! ¡Las lecciones!”, ao que os nenos responden "medrosos, alicaídos, y a saltos los corazones; libros sucios y ellos casi andrajosos y tristes (...), porque no han estudiado, recelosos..."30. Con todo, os cativos

\footnotetext{
$\overline{25 \text { Vida Gallega }}, 511$ (10 de febreiro de 1932), páx. 9.

${ }^{26}$ Vida Gallega, 71 (10 de xuño de 1916), páx. 8.

27 Vida Gallega, 71 (10 de xuño de 1916), páx. 8.

28 Vida Gallega, 71 (10 de xuño de 1916), páx. 8.

29 Vida Gallega, 526 (10 de xuño de 1932), páx. 27.

30 Vida Gallega, 526b (10 de xuño de 1932), páx. 1.
} 
NA ESCOLA, por Xaime Prado.

20 de Noriembee de 1931

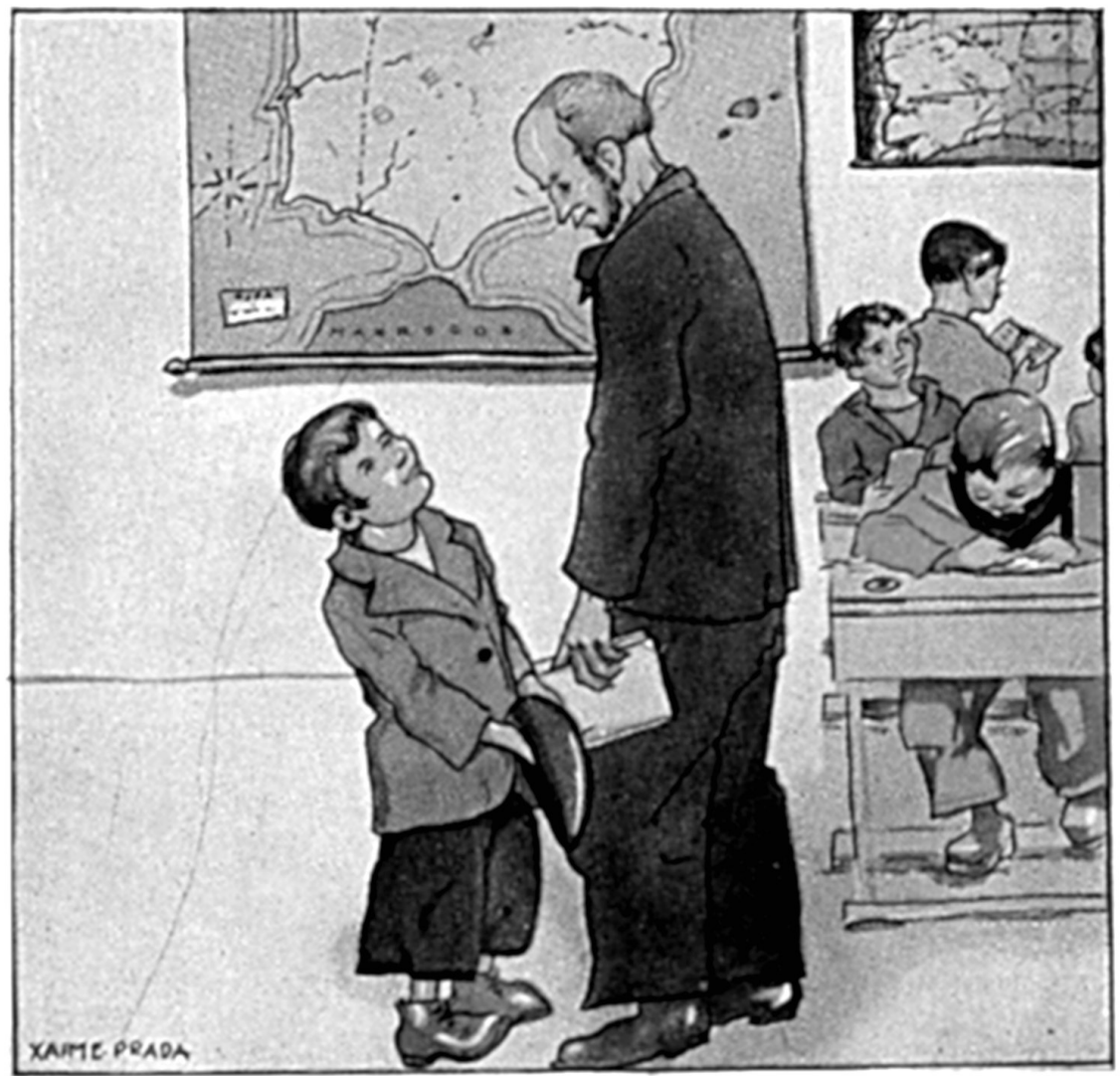

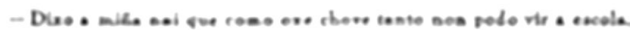

Fig. 4. Na escola, por Xaime Prada. En Vida Gallega, 20 de novembro de 1931, núm. 503, páx. 1.

presentes nas viñetas gráficas con pé de texto e nalgúns breves textos, conseguen transformar a relación de sometemento ao autoritarismo dominante dos mestres empregando a súa picaresca; mostra disto pode ser a seguinte imaxe de Xaime Prada, na que o neno fai saber ao mestre: "- Dixo miña nai que como hoxe chove tanto non podo vir á escola"’31.

\footnotetext{
$\overline{31 \text { Vida Gallega }}, 503$ (20 de novembro de 1931), páx. 1.
} 
VI) Os edificios escolares: centros do progreso

As alusións aos espazos escolares aparecen de modo reiterativo en Vida Gallega, habitualmente baixo as representacións de elementos reais (espazos físicos, "obxectivos") e/ou vividos (espazos psicolóxicos, percibidos, "subxectivos") $)^{32}$. Nesta liña, preséntanse detalladas descricións das edificacións escolares, que destacan pola súa fermosura e iluminación. Pero as obras escolares ás que maior atención se presta desde Vida Gallega, en consonancia coa relevancia que a cuestión da emigración galega a América acada na revista, resultan as denominadas "escolas de americanos", que constitúen unha referencia constante na publicación. Precisamente, unha das asociacións máis activas nese ámbito, a Unión Hispano Americana Pro Valle Miñor, que sufragou importantes proxectos educativos na zona do Baixo Miño, contará cun amplo espazo nas páxinas da revista. Expresión desta presenza é a extensa sección de textos e fotografías de José Gil destinada, entre as páxinas 14 e 15 do número 75 de Vida Gallega e baixo o título "Los milagros del patriotismo gallego", á escola de "Valle Miñor" situada en Gondomar.

Lóubase, pois, na publicación, o labor filantrópico dos emigrantes galegos, aproveitando para facer gala do ben que lles foi económicamente no éxodo. Así, preséntanse pormenorizadas descricións de escolas, como a creada en Lavadores "por el ilustre filántropo D. Ramón Nieto" 33 - escola á que, tamén, se destina a galería fotográfica da páxina 20 no mesmo número da revista-, na que:

los cuatrocientos alumnos de ambos sexos, que concurren diariamente a las clases, pueden adquirir una preparación completa de lo que comprende la Primera Enseñanza, graduada, así como los conocimientos precisos de contabilidad y mecanografía, como especialidades.

Disponen las Escuelas, también, de una magnífica huerta-jardín, donde los niños hacen prácticas en el cultivo de cereales, plantas de todas las clases y flores, y todo el tecnicismo que requiere el laboreo de la tierra para su mayor fertilidad ${ }^{34}$.

\footnotetext{
32 Atendemos, para establecer estas designacións, ás propostas de Antonio Viñao Frago, "Escolarización, edificios y espacios escolares", CEE. Participación Educativa, 7, 16-27, 2008 a respecto dos espazos escolares.

33 Vida Gallega, 526 (10 de xuño de 1932), páx. 27.

34 Vida Gallega, 526 (10 de xuño de 1932), páx. 27.
} 


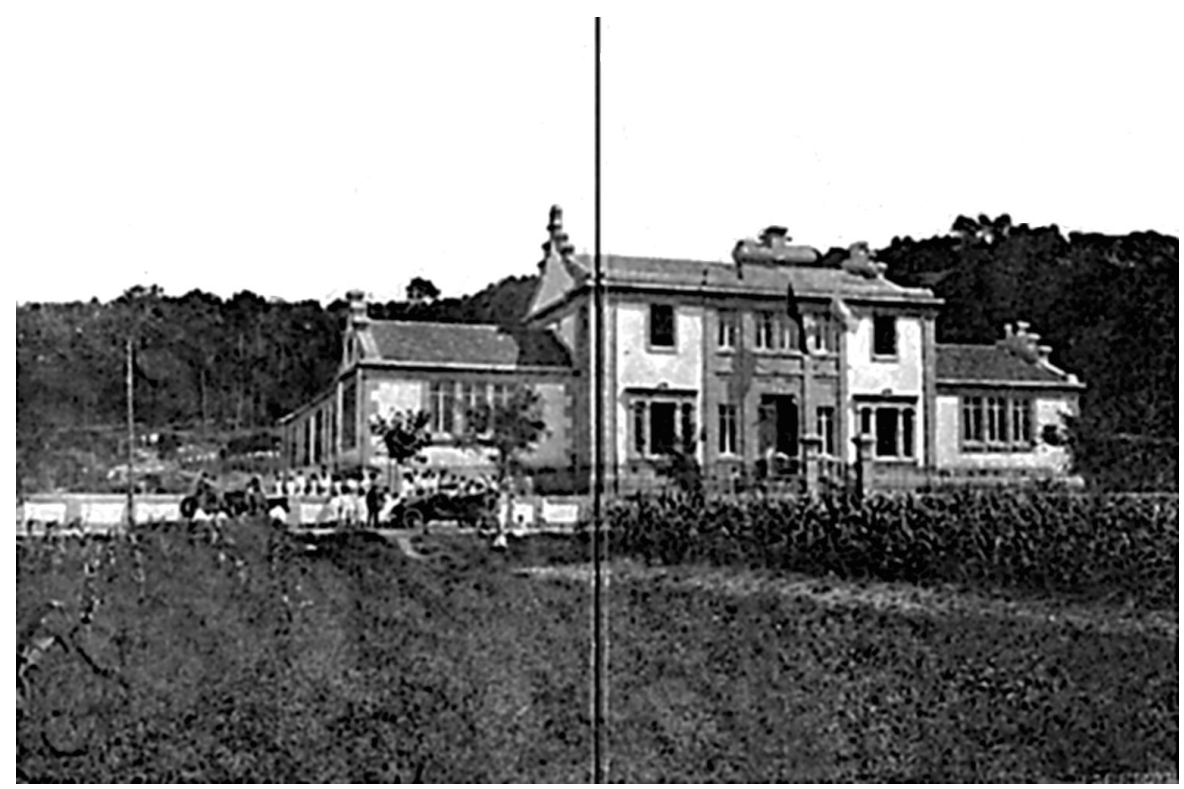

Fig. 5. Los milagros del patriotismo gallego, por José Gil. En Vida Gallega, 15 de setembro de 1916, núm. 75, páxs. 14-15.

\section{A ReVista CÉLTIGA}

Céltiga nace en Bos Aires (Arxentina) o 30 de setembro de $1924^{35}$, fundada polo que fora antigo dirixente da Casa de Galicia, Domingo Rial Seijo (quen exerceu como xerente e administrador da revista) e polo debuxante Ramón Peña, levando inicialmente por subtítulo: Revista Gallega de arte, crítica, literatura y actualidades: Publicación quincenal editada por la Editorial Céltiga. Na súa dirección literaria figurou, a partir do 30 de outubro de 1924, Adolfo Vázquez Gómez e, con posterioridade, Eduardo Blanco Amor, Ramón Suárez Picallo e Eliseo Pulpeiro.

Este órgano de prensa configurouse como voceiro de intercambio e de encontro da intelectualidade galega residente na Arxentina da emigración, actuando con vocación de ponte entre Galiza e Hispanoamérica. Orientada por unha ideoloxía e sentimento galeguista (ben perceptíbel e acentuada coa aparición da sección Idearium galeguista a partir de outubro de 1925, na que se reproduce a principal obra de Risco, Teoría do nazonalismo galego), colmaba as súas páxinas de lou-

\footnotetext{
35 Se ben xa no ano 1920 os galegos Domingo Rial Seijo e Ramón Peña fundaran unha publicación baixo a cabeceira de Céltiga, cunha efémera duración e escasos números publicados, que non foi tomada en consideración no seu rexurdir posterior.
} 
banzas á "patria galega", actuando en prol do mutuo coñecemento e intercambio entre a Galiza territorial, a Galiza emigrante e, particularmente, Arxentina ${ }^{36}$. Así, procuraba espallar ideas e dar a coñecer problemáticas propias da situación vivida nas "dúas Galizas", acudindo a unha permanente exaltación da terra e da galeguidade. Neste sentido pode afirmarse que Céltiga constituíu unha "cabeceira que desempeñou un papel crucial no proceso de afirmación e desenvolvemento do galeguismo entre as comunidades galegas de América"37.

Os propósitos da publicación serían ${ }^{38}$ :

a) modernizar e enriquecer a cultura galega mediante a súa expansión e apertura ao diálogo coas culturas iberoamericanas; b) defender os postulados do galeguismo de maneira pragmática e moderada, abríndose ademais á posibilidade de servir de voceiro oficioso aos nacionalistas de Galiza, acollendo as tendencias máis republicanas dentro do mesmo; e c) crear un produto editorial de calidade, tanto estética como de contidos, que contribuíse a aumentar o prestixio da colectividade inmigrante perante a sociedade receptora.

Nela poden lerse crónicas e artigos con novas e información sobre as sociedades galegas de emigrados, cuestións ás que se destinan especialmente as seccións Motivos de Crónica ou El momento de Galicia, que analizan a actualidade galega e da colectividade emigrante. Aprécianse tamén variados textos de creación literaria e artigos de asuntos culturais; obsérvanse fotografías de paisaxes e de cidades galegas; así como un amplo e variado material de ilustración integrado por viñetas, debuxos, caricaturas, gravados e fotografías.

Constitúen temas recorrentes o referido á infancia (en Páginas infantiles, ou a través das fotografías en Pequeños tiranos), á educación (destacando as páxinas denominadas Apuntes Pedagógicos), á muller (Labores femeninas), á información das asociacións galegas da emigración (Por nuestras sociedades), entre outras. Existían na revista determinadas seccións de publicación fixa, tales como: Motivos de crónica, de Luis de Neda (pseudónimo de Adolfo Vázquez Gómez); Bibliografía y periodismo, de Santiago Gómez Tato; Teatros, de Paz Hermo; Pá-

\footnotetext{
$\overline{36}$ Neste sentido ten sinalado X. M. NúÑEz SEIXAs, O soño... páx. 212, que "Céltiga procurou presentar o rostro ignorado da cultura e das tradicións galegas ao público arxentino, combatendo ao mesmo tempo os estereotipos negativos existentes na esfera pública do país cara os inmigrantes de Galiza, patentes na literatura popular, o teatro e a prensa gráfica”.

37 Sylvia Pulpeiro e Pablo Rodríguez (eds.), Eliseo Pulpeiro. As letras galegas entre dúas ribeiras (Ribadeo e Río da Prata), Santiago de Compostela, Consello da Cultura Galega, 2016, páx. 9.

38 X. M. NúÑEZ SEIXAs, O soño... páx. 212.
} 
ginas infantiles, de Adolfo Vázquez Gómez; Juicios que suscita Céltiga; Actos y fiestas de nuestras sociedades; Paisajes gallegos; Paisajes argentinos; Temas gallegos; Por nuestras sociedades; Firmas celtas, de Manuel Linares Rivas; Idearium galeguista, de Ramiro Isla Couto; Temas del agro gallego, de Suárez Picallo; entre outras.

A liña de pensamento ideolóxico que Céltiga mantivo ao longo da súa andaina, variou con certos matices de intensidade, mais camiñando nas dimensións do ideario republicano e do galeguismo nacionalista ${ }^{39}$; a este respecto convén sinalar que:

\begin{abstract}
En calquera caso a liña do galeguismo nacionalista de Céltiga conta co antecedente de Eduardo Blanco Amor, que emigra a Bos Aires en 1919 e dende alí divulga o maxisterio ideolóxico de Risco, que entende necesaria a creación dun grupo galeguista que, relacionado coas Irmandades galegas, consolide e propague a doutrina galeguista e afirme naquel contexto castelanizante o emprego do idioma galego ${ }^{40}$.
\end{abstract}

Atendendo á cuestión lingüística, Céltiga constituíu unha revista bilingüe con maior protagonismo do castelán aínda que, en anos posteriores e coa incorporación de novos colaboradores, a presenza da lingua galega irá en aumento. As achegas de Evaristo Correa Calderón, Portela Pérez, Vicente Risco, Ramón Suárez Picallo, Antonio Noriega Varela, Luis Porteiro, Leandro Carré ou Lugrís Freire, camiñaron neste sentido.

Entre os colaboradores literarios da revista cultural ilustrada, na inmensa marioría varóns, destacaron: Eduardo Blanco Amor, Ramón Cabanillas, Zapata García, Amado Carballo, Xabier Bóveda, Alfonso R. Castelao, Avelino Díaz, Wenceslao Fernández Flórez, Manuel Leiras Pulpeiro, Manuel Linares Rivas, Manuel Oliveira, Xosé Lesta Meis, Xosé Ares Miramontes, Roberto Blanco Torres, Lino Pérez e Xosé Filgueira Valverde, entre outros.

A periodicidade da revista é quincenal, saíndo habitualmente publicada nos días 10 e 25 de cada mes, e o seu número de páxinas adoita oscilar entre as 32 e as 40 , se ben estas vense notabelmente incrementadas nos números extraordinarios. Con todo, houbo unha paréntese na publicación de Céltiga (entre o número 11, publicado o 28 de febreiro de 1925, ata o 25 de xuño dese mesmo ano) debido, como indica Eliseo Pulpeiro no número 12, a dificultades económicas.

\footnotetext{
39 Luis Alonso, Élida Abal e Alexandra Cillero, Céltiga (1924-1932). Revista Gallega de Arte, Crítica, Literatura y Actualidades, Xunta de Galicia, Secretaría Xeral de Política Lingüística, Centro Ramón Piñeiro para a Investigación en Humanidades, 2009; e S. Pulpeiro e P. Rodríguez, Eliseo Pulpeiro...

${ }^{40}$ L. Alonso, É. Abal e A. Cillero, Céltiga..., páx. 12.
} 
As ilustracións da revista incidiron en que esta fose apreciada pola súa calidade estética e artística, ademais de pola relevancia intelectual dos seus colaboradores. Son representativas as reportaxes fotográficas sobre as paisaxes e as principais cidades galegas, así como as fotografías correspondentes a eventos e acontecementos sociais importantes tanto nas cidades galegas da emigración como nas da Galiza de aquén mar. O material ilustrado que aparece é coidado, múltiple e heteroxéneo: viñetas, gravados, debuxos, óleos e caricaturas, enchen as páxinas de reproducións dos artistas galegos máis recoñecidos.

\section{A INFANCIA REPRESENTADA EN CÉltiGA}

A infancia aparece representada en Céltiga a través de fotografías, viñetas, debuxos, gravados, textos e ilustracións. Tanto a través da publicidade, como das crónicas e novas, os suxeitos infantís son retratados desde un mundo adulto que mostra interese por destinarlles un rol protagonista, aspecto que se torna ben perceptíbel nas seccións Páginas infantiles ou Pequeños tiranos ${ }^{41}$. Podemos dicir que aos nenos e ás nenas se lles outorga na revista ilustrada unha presenza relevante (que non abundante), malia que fisicamente ocupen un espazo reducido-como se aprecia no gráfico que presentamos a continuación-, correspondente ao 5'53 por cento das páxinas revisadas. Neste sentido, valoramos que existe en Céltiga o interese de dotar de visibilidade ás crianzas e á súa educación en parte debido ás implicacións que isto pode ter para o proxecto político entre galeguista e nacionalista galego que subxace ás páxinas da revista (con moi diversos matices), no que é reiterativa a idea de infancia como "xermolo do futuro" e "semente" do porvir da "nazón galega". É así que os anhelos de cambio sociopolítico fican depositados nunha educación encamiñada ao coñecemento do propio, ligada á contorna rural de orixe, na que a escola xoga un papel crucial para o "progreso" ansiado.

Porén, son múltiples os silencios que se trasladan a través da revista ilustrada con respecto ás representacións dos nenos e das nenas; e pode apreciarse que, co paso dos anos da edición da revista, este baleiro aumenta notabelmente (así podemos aprecialo na gráfica que presentamos a continuación). Destacamos que entre os anos 1924 (inicio da publicación) e 1927 é cando se observa un maior número de representacións, sendo no 1925 cando se aprecia un maior número de imaxes e de textos que remiten á cuestión que estudamos (constituíndo unha totalidade de 69 imaxes e de textos), o que semella estar ligado á presenza na redacción da figura do masón e progresista Adolfo Vázquez Gómez, logo ausente deste proxecto. Observamos tamén que o notábel descenso das representacións vese acentuado

\footnotetext{
$\overline{41}$ Seccións ligadas á presenza nos primeiros momentos de Adolfo Vázquez Gómez, que máis tarde desaparecerán.
} 
Gráfico 3. Relación entre a totalidade de páxinas consultadas e as extraídas para o estudo das representacións en Céltiga.

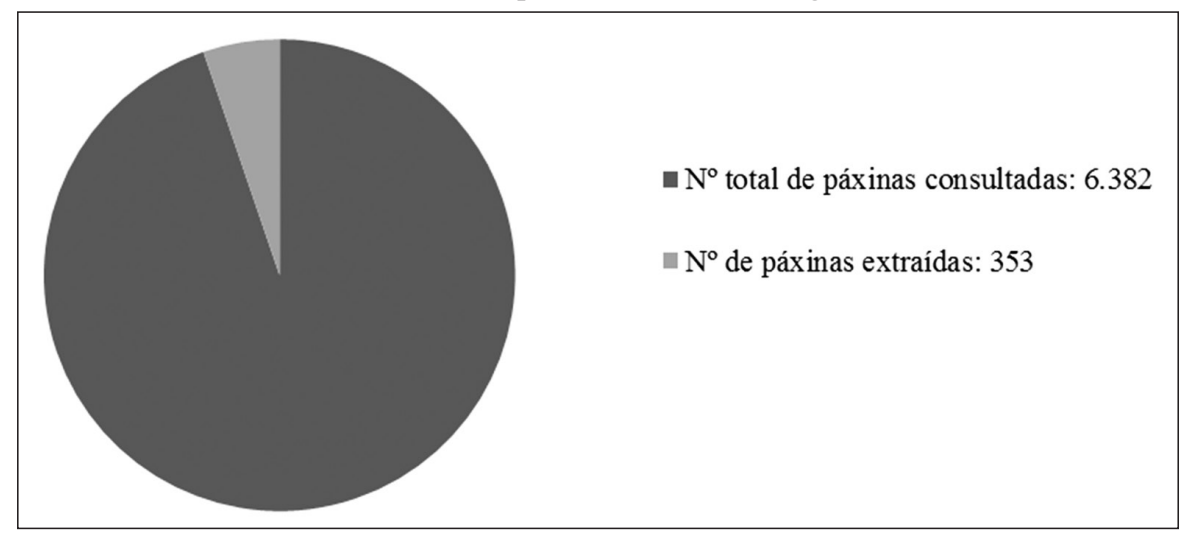

Fonte: elaboración propia.

Gráfico 4. Páxinas extraídas para o estudo das representacións (por ano) en Céltiga.

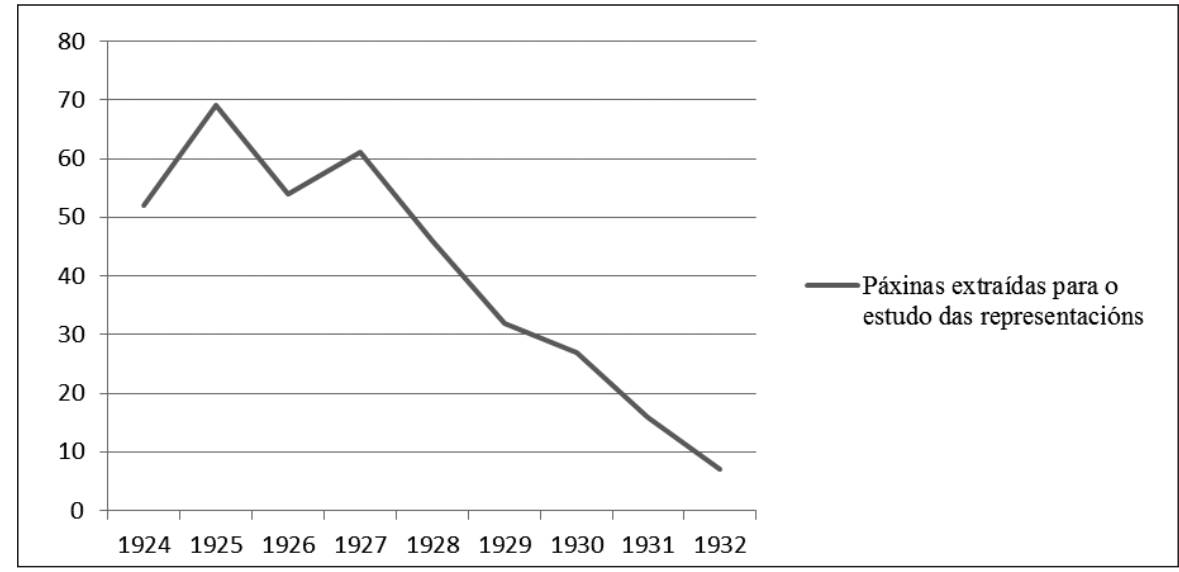

Fonte: elaboración propia.

no 1932, en boa parte xustificado debido á desaparición da publicación no mes de xullo. En canto ás portadas protagonizadas por nenos e nenas, estas constitúen unha totalidade de 11 páxinas, das cales catro foron publicadas no ano 1930.

Por outra parte, tomando en consideración as datas de publicación das diversas alusións á infancia e á súa educación, obsérvase certo incremento das mesmas entre os meses de decembro e febreiro, pois "había determinadas épocas nas que se escribían un maior número de artigos alusivos aos nenos, as máis importantes, no Nadal, a finais de decembro e a principios de xaneiro, momento 
no que a sociedade estaba sensibilizada de xeito especial con todo o relacionado coa nenez" ${ }^{\prime 2}$

A presenza de representacións masculinas é substancialmente superior á correspondente co xénero feminino e, neste caso, aludimos non só á prevalencia da figura do home (neno, adolescente ou adulto) fronte á da muller (nena, adolescente ou adulta), senón tamén á maior presenza de metáforas que empregan a masculinidade asociándoa a rangos de superioridade, fronte á feminización daqueles aspectos aos que se confiren roles de subordinación ${ }^{43}$. A estas expresións do patriarcado, engádense as cuestións de clase social e de territorio, sobrepoñendo a tríade "masculino- clase alta- urbano (vida pública)" á conxugación "femininoclase baixa- rural (vida privada)".

Con estas consideracións previas, procedemos a presentar os tópicos ou unidades temáticas que valoramos cun maior protagonismo en Céltiga en relación ás imaxes de infancia e da súa educación que aparecen representadas:

\section{I) Infancia como "xermolo do futuro" na que depositar as "espranzas do porvir".}

Nas páxinas de Céltiga, o neno (en ben maior medida que a nena) aparece retratado como "suprema espranza da Patria galega" 44 ou como "retoño da raza" 45 , polo que se concibe a súa existencia en perspectiva de futuro, como semente do porvir da terra. Neste sentido, outórgase á educación unha crucial importancia, porque "los niños de hoy formarán los hombres del mañana, y (...) toda nación debe tender a aumentar su población con hombres sanos y fuertes que constituyan el comercio, las letras y las artes"46.

É por iso que a educación é concibida -sobre todo a medida que avanzan os números da revista- como un proceso de aprendizaxe e de (auto)coñecemento ligado á contorna máis próxima, na liña que expresa Eduardo Blanco Amor e que incorporamos nos parágrafos seguintes:

\footnotetext{
$\overline{42}$ Diana Vilas Meis e Óscar Rodríguez García, Cousas de nenos. Unha aproximación á representación da infancia en Cousas da vida de Castelao, Pontevedra, Deputación de Pontevedra, 2014, páx. 44.

${ }^{43}$ Nesta liña podemos aludir aos traballos en perspectiva feminista de Carmen Blanco que critican a violencia exercida polo discurso nacionalista galego tradicional contra as mulleres (Carmen BLANCo, "Mulleres na utopía celta de Pondal”, en Unión libre: Cadernos de vida e culturas, 2, 1997, páxs. 101-118), aos textos de María Xosé Queizán, ou ben á obra de Helena MiguÉLEZ-CARBALleira, centrada na aproximación á politización do nacionalismo como proceso discursivo marcado por unha retórica de xénero, no que tendeu a prevalecer unha "estratégia pela qual se feminiza aquilo que se pretende desvalorizar" (Galiza, um povo sentimental? Género, política e cultura no imaginário nacional galego, Santiago de Compostela, Associaçom Galega da Língua, 2014, páx. 20). Estas teorías enlazan coas argumentacións de Janet Sorensen (The Grammar of Empire in Eighteenth-Century British Writing, Cambridge, Cambridge University Press, 2000) ao recoñecer a centralidade das cuestións de xénero nos xogos de poder imperialistas.

${ }^{44}$ Céltiga, 22 (25 de novembro de 1925), páx. 11.

45 Céltiga, 16 (25 de agosto de 1925), páx. 15.

46 Céltiga, 26 (25 de xuño de 1925), páx. 26.
} 
Queremos que cada niño gallego conozca el suelo que pisa y las gentes que lo habitan; de donde viene su raza y adonde va; la ciencia sencilla que le haga hermano atento de las plantas familiares y amigo de las bestias humildes que ayudan a ganar el pan; y atento observador del mar, que es fuente de tesoros y hervidero de bellezas. Hacerle consciente y sensible de los encantos y de la riqueza de su tierra. Romper hasta donde sea posible la rutina salvaje fomentada por una pedagogía filistea que obliga al niño gallego a saber quién fué el bruto de D. Enrique de Trastamara, y no se le nombra al padre Feijóo, que le llena la cabeza de monos sabios de Samaniego y se le deja ignorar a Curros y a Lamas; que le habla de unos caballeros barbudos que mataban moros y no se le dice quien labró el pórtico de Compostela ${ }^{47}$.

A visión nacionalista tende a verse reforzada a medida que avanzan os números da revista, se ben apreciamos xa algúns exemplos nos primeiros anos da publicación:

Cariña churrusqueira e doce, que han de queimar os soles candentes dos trópicos, ou que han de escartillar as neves xélidas dos polos, ou que han de chapuzar os salseiros de todol'os mares do mundo. ¿Que pr'a todo has de servir, retoño da' Raza!

Eses teus peíños, acariñados pol'as froles do noso chán galego, e hastra pol'as espiñas feras e irtas, que non se estreven a rabuñal'os, santificados como están pol'os terróns d'a terra fecundada, han de hollar todol'os camiños, n'o teu futuro pelegrinaxe de emigrante.

¡E coido que xa pensas n'eso!

Debaixo da túa pucha aldean xa bolen e rebolen os pensamentos da fuxida pr'a terras estenas, fiela a tradición aventureira da tua estirpe nómade ${ }^{48}$.

Neste caso, proxéctase para a infancia, ademais, o futuro da emigración, ben presente nas páxinas de Céltiga; unha emigración que non esquece nunca a "ter-

\footnotetext{
47 Discurso de Eduardo Blanco Amor, "leido en el Festival Pro Libro Escolar Gallego", por Eduardo Blanco Amor. En Céltiga, 45 (10 de novembro de 1926), páx. 8.

48 Por Suárez Picallo. En Céltiga, 22 (25 de novembro de 1925), páx. 11.
} 
riña" retratada nas contornas rurais de orixe ${ }^{49}$. Desta maneira, tanto a través do texto como da imaxe (como podemos observar na imaxe do Neniño galego que presentamos), aprécianse escenas de tipo costumista a modo de leitmotiv, que representan a vida no rural galego. Podemos dicir que se toma como referente nestas representacións da infancia en Céltiga a Os nenos de Filgueira Valverde, libro editado por vez primeira no ano 1925, que aparece reiteradamente na publicidade da revista desde o ano da súa publicación e ao que se alude explicitamente nalgúns textos, polo feito de reflectir aos "verdaderos nenos gallegos":

Estos niños de Filgueira Valverde, tan espontáneos y naturales, no tienen nada que ver con esas resabiadas criaturas de 'Kindergarten', de los rebañitos escolapios, o de los primeros años del instituto: niños recoletos, formalitos y sesudos, con esa precoz sabihondez que prestan las gafas de carey y las corbatas anudadas 'a lo hombre grande', so la tiranía del cuello almidonado y geométrico. Estos nenos de Filgueira-verdaderos nenos gallegos-viven sus años y su medio. Suben a las paredes, roban uvas, se rompen la crisma a sopapo limpio, tienen miedo a los muertos, lo que es natural, encuentran absurdas a las institutrices que enseñan el francés a los hijos de los ricos, y se ríen de los papás que no dejan a sus niños hablar nada en gallego, ni siquiera decir 'fiuncho', como la fidalguiña del cuento de Castelao (...). Y mientras tales esfuerzos son posibles en la tierra pobre de Galicia, nosotros, los rumbosos americanos, permanecemos papando moscas, y cuando queremos humoristas, compramos las indecencias de Belda y damos a leer a nuestros hijos - por toda lectura infantil-las paparruchas blandengues de D’Amico, o las cursilerías tristonas y veladamente pornográficas de aquel fraile Calpena, de infelice memoria.

Con ésto, con hablar media hora diaria en el café sobre los asuntos de la patria, y con no dejar decir a nuestros hijos 'fiuncho', vamos a echar buen pelo los gallegos ${ }^{\text {"50 }}$.

\footnotetext{
$\overline{49}$ Este aspecto (que aparece reiteradamente na revista ligado ás nocións de nostalxia, saudade e/ou melancolía) conecta coas afirmacións de H. Miguélez-CARballeira, Galiza, um povo.., páx. 14, ao sinalar que "nas representações modernas do País, da súa língua e da súa gente, o tropo do sentimentalismo galego aparece reiteradamente como marcador étnico, formando um continuum, que abrangue o corpus textual e visual da história e da cultura galegas, desde fins do século XIX até aos nossos días. As suas manifestações são tão várias como historicamente complexas, mas todas elas confluem em presumir que o galego é um povo nostálgico, que vive em harmoniosa comzunhão com a paisagem ou, então, em pesarosas saudades, quando longe da terra". Así, podemos apreciar que o vínculo afectivo e emocional á idea de pertenza e identidade nacional é común nas páxinas de Céltiga.

${ }^{50}$ A propósito de "Os nenos" de Filgueira Valverde, por Critias (pseudónimo que adoitaba empregar Eliseo Pulpeiro). En Céltiga, 33 (10 de maio de 1926), páx. 22.
} 


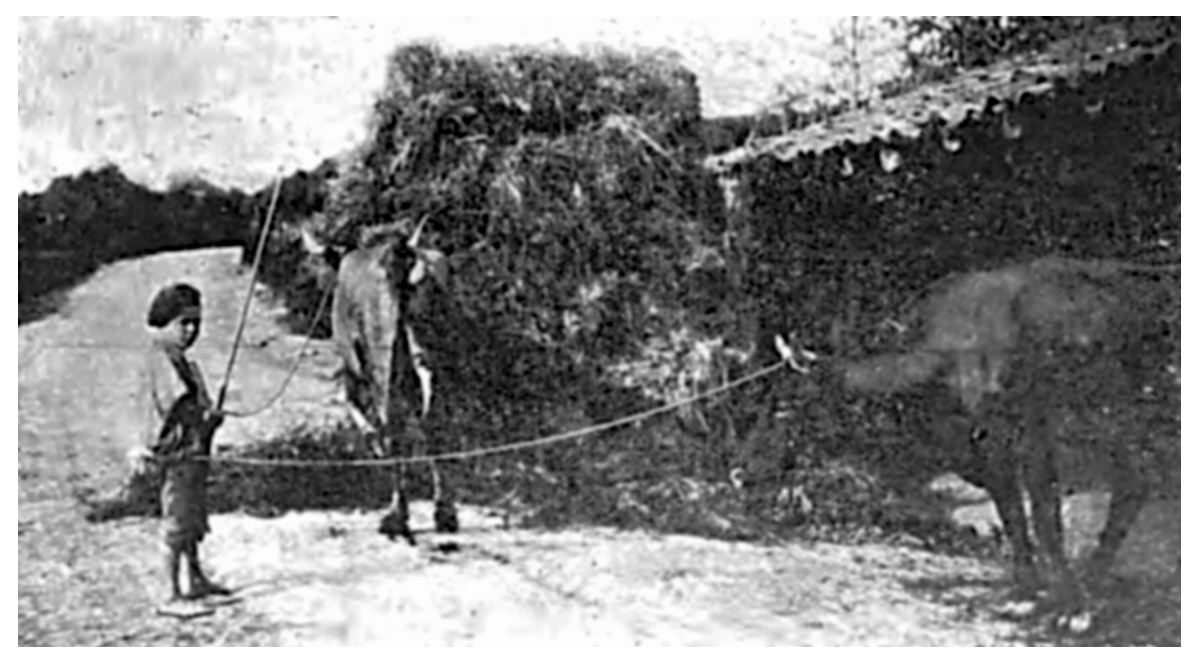

Fig. 6. Neniño galego. En Céltiga, 25 de novembro de 1925, núm. 22, páx. 11.

II) Infancia destinataria das Páginas Infantiles: nenos como suxeitos activos e protagonistas na construción do porvir.

A infancia é contemplada en Céltiga, como sinalábamos con anterioridade, tal que "xermolo do futuro" no que a sociedade adulta deposita as súas arelas de mudanza socio-política. Pero esta visión non traslada aos suxeitos infantís a un plano de pasividade nas representacións, senón que estes son tratados como partícipes e protagonistas na construción dun futuro social e político común. Así pode apreciarse nas Páginas Infantiles de Céltiga, destinadas a "los niños que lean Céltiga (...). Pequeños lectores de Céltiga" 51 , narracións que toman forma de anécdotas, reflexións con compoñente histórica e moral, contos ou fábulas, das que poden extraerse leccións e máximas. Estas páxinas posúen unha intencionalidade didáctica, a pesar de que a linguaxe que empregan semella dirixida a un público lector adulto.

Nas Páginas Infantiles das que falamos, tamén se destinan espazos aos xogos infantís, aos traballos manuais, aos contos e aos chistes.

III) Infancia rural e "urbanidade”: cuestións de clase, xénero e distinción social.

En relación ao contexto de pertenza dos nenos e das nenas, percíbese unha clara dicotomía en Céltiga que determina as súas representacións: a crianza

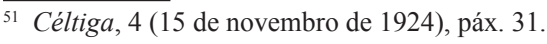




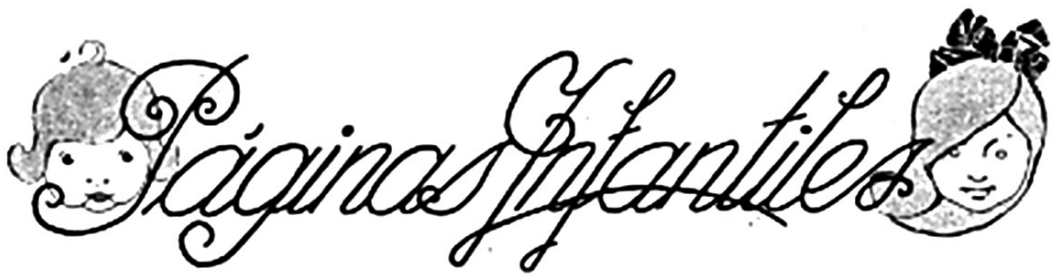

I.OS VEcrios

F $\mathbf{x}$ dos baloones inmedlatos se pasaban los dias E un juruero y on canario, caes uno en ro jaula. Al prineiglo, como eran 40 distinta carta, miraronee

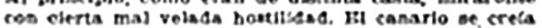
de una rase mis alselingulda. iPoe alco era completatweste amartisa, y por alzo tambisn, cuasdo cantaty to hecta deerranando wus notan largax llenas $y$ monoras, que invadtan el aire en emalas ce una fuerza prodisloes! En cambla el glecuero so ufasaba de va pardo plumaje, con tanto orgulda, jor to menos, como un cardenal do va manto ondoeo or rojo.

Pero pasearon los stak $y$ con sa roce continus fueron desapareciendo aquevias aopertess y hapta lleca. ros a entablar amiotocos coloquion en ba que se revelaron wa mutieas afcertonen, wa cartho por tote o ot otro atimento, au prosibertion por los dias azules, geveros y disfance coando la Naturateda abre gun entrafias al ool y leviata los cilices de us fiores

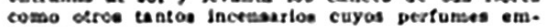
briacan of alma.

El canarto extaba olompre aiekre. Bn camblo, at gliaraerills os ponia a to mojor, $y$ ath motivo aparente. en extrems trate. Fato extrahaba mucho a su veriso. ot cuat un dia, viondoso de tal cuina, como to revelatan to hueco \&o wa piumaje. bo triate de vas pa. pDM y to caedizo de ral alm, no puco contererse, aomando la dordea cabecita por to platerdas alam. bres, is presunto

- LQue to ocurre. amirulto mis?...

$\rightarrow$ inda.

- ivada y cutse tan triate?

-Teaso "rpieen". como on hombrecto brithnico. -Y dpor que : Ambos Doseemos agua on abun. dancls. alptate y canamoner atn escanez $y$ ol cartho entrasible de nuegras lisas amitu.

- Mira, ta no puedes aber nada de $\mathrm{ml}$ dolor por. que, entro othis cosar ta tenorna on que puedo run. darbo. 2 A gua no abes que no bio viva el plearo de la besida 7 del comer benta el harturzo?

-Mo dejes turulato...

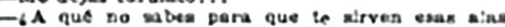
tan doraces $y$ tas termosas?

- Para matenr por is lavia. por trofe: yo cruce el -ix Jars alco mse!... Yo rof tiofe: Yo cruce el ebsaclo ea toda sa extenition: yo, cuando tuve med, reeurrt a uta fontana que hacks satenr muk axuse blanvios chaparra: yo, al entir el eappaso del sambe. vi coms el sampo se abria eual un gtcantesco comeGero: yo tave us nddo... iAy! Dichoos aquel que con-

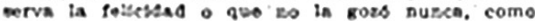
to: ...

Y if glguero, callanda, hunals me cabecile blassulrroja bajo su sia zzquilerse como no gueriendo ver e) día rectente nl el cleto azal...

Jose A. Leveneo.

\section{CHISTES}

- Mra, mame me desplertas euanos tenga hambre. - Huso mis by eomo voy a saber yo cuando the nes hambre?

- Poes cuanso me desplertex $z$ no to digo que no to hagas besta soe is tenga?
EI, EMIIGRATE

80 cortan de un cartica crueso, das redendeies de 10 a 12 centfinetron te ancho como on indika en $A$

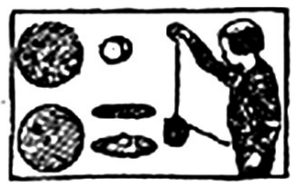
Y B. 8e toma un pe. dazo de corcbo de un cer:timetro de xrueso conso so ve on C. $y$ te pora cada jaco del corctio con el centro de los diteca de cas. ton, como muevtra el eibajo.

se ata alrescer del concso la pusta de un hilo reelezente. coms de us metro do larzo y en el otro extresso on hase un tass para poser panar la punt del 4nda, luego on enroetve a manera de carretes, ol hilo alrededor del sorcho, se suelia ol a garato $y$ to deseveliend raplianiente, pero at al liekar al flral del bilo m te imprima una peruets sacúdjs de abs. to bacta arriba, ge vers al faxuete recocrer of larko del Milo. $y$ que oe enzoscara alrededor del corrto en direceión contraris. 81 ae continda haciendolo ba. jar y vable alternativamenth of juero te hace mal

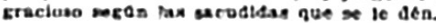

\section{EL HOSBRE SIN CABEZ.A}

Debldo a la precipl. tactsa det pintor, ... ha quedado ento elerante min lu:tr la par. to mia noble de au coerpo.

No to dejaremon ant decoplata invito mla lectorcition surs que te fabriguen ans cabera, ya ma disu. Hotola on et erracto corresponainste o $\mathrm{rc}$ leuna tizura y taexo adaz taria al crabsodo. don de pueden peraria.

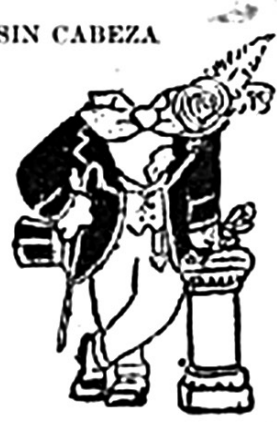

\section{FI. AERONAUTA}

Cortama un monigote de papel. como el de is

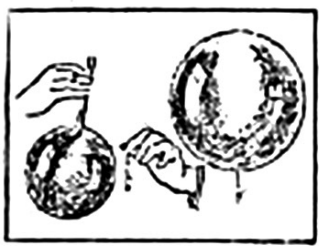
rixara, $y$ le raen. mos por la catera un silita, dejando to sujeto por un nodo on us extre. ma. Ken el otro extre mo ieva una ro dafles de pape

Nosemos tisera. mente la rodajita $y$ is ccercamoe la burbuje, a is cual so adnsere. 81 is burbuja se ha hecho debloa. mente, tendra reoisenets bastante para sontecer al acronarta.

Fig. 7. Páginas infantiles. En Céltiga, 15 de febreiro de 1925, núm. 10, páx. 38. 
desenvolvida no contexto rural, ou ben no contexto urbano. Ao aludir á infancia situada no rural destácanse como positivos aqueles valores ligados ao mundo do traballo (fundamentalmente no campo), así como a independencia nas angueiras dos suxeitos infantís, tendo correspondencia coas representacións que Filgueira Valverde ofrece en Os nenos.

Por outra parte, ao atender á infancia que desenvolve a súa vida cotiá nas cidades, as representacións tenden a facer fincapé en valores como a inocencia e a dependencia. Podemos falar entón dunha dicotomía nas representacións da

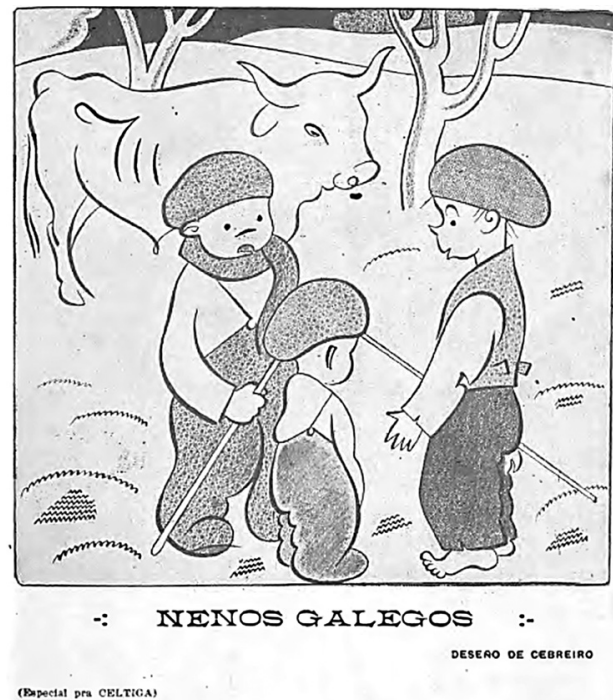

Fig. 8. Nenos galegos, por Cebreiro. En Céltiga, 25 de xullo de 1927, núm. 62, páx. 23. infancia segundo o seu contexto de pertenza rural ou urbano: dunha banda situaríase a "infancia independente e traballadora do rural" e, doutra banda, a "infancia dependente e inocente do urbano". A esta dicotomía que percibimos, engádese o valor da "galeguidade" (e da preservación dos valores do "mundo galego"), que se vincula co "rural", denotando así certa conciencia de pertenza e clase social; e a cuestión de xénero, pois a "infancia independente e traballadora do rural" tende a ser masculina, mentres que a "infancia dependente e inocente do urbano" adoita aparecer representada en feminino, e mais ben ligada a espazos de ocio e de consumo. Así podemos aprecialo mediante a publicidade, na que a muller é a fundamental destinataria daquelas mensaxes publicitarias relacionadas cos coidados persoais -hixiene, saúde, estética- e do fogar.

Estes roles de xénero ligados ao contexto rural ou urbano mudan se nos referimos á ocupación dos espazos sociais ou "públicos" (externos á vida no lar) fronte ás contornas privadas; neste sentido a muller aparece asumindo as responsabilidades dos coidados da familia e do fogar que tradicionalmente lle veu asignando o patriarcado, mentres que o home adoita ocupar espazos públicos de sociabilidade. Esta ambivalencia patriarcal podería relacionarse co rol tradicional da muller nos lares galegos, onde se lle responsabilizaba das tarefas domésticas; cuestión que, unida á historia da forte emigración masculina, fixo recaer nas mulleres as responsabilidades non só do fogar e dos coidados familiares, senón tamén das terras. 
IV) Infancia na familia extensa rural ou na familia nuclear urbana. Roles de xénero como expresión do patriarcado na familia.

A representación das relacións interfamiliares que aparecen en Céltiga condensan, ao noso parecer, os trazos definitorios das relacións dos pícaros cos adultos encargados da súa crianza. Os vencellos e interaccións entre os membros da familia, derivados da convivencia, atópanse influenciados por diversas variábeis, tales como: a situación socioeconómica familiar; a idade, formación e sensibilidade dos pais; a actitude que adoptan ante o fillo ou filla en conexión co coñecemento que teñen da infancia e do seu proceso madurativo; ou a influenza que exercen na familia as persoas -familiares ou non- que convivan baixo o mesmo teito ${ }^{52}$.

O sedimento patriarcal aparece reproducido a través de todas as representacións que poden apreciarse na revista e, concretamente, cando se fai alusión ao ámbito familiar, o estereotipado dos roles prevalece tanto nas imaxes presentadas da familia extensa propia do contexto rural como no caso da familia nuclear, máis común nas contornas urbanas.

Os estereotipos de xénero trasládanse tamén ás figuras dos suxeitos infantís, non só mediante a marcada expresión das interaccións nos roles familiares, senón no que propiamente pode agardarse deles e delas como futuros adultos. Deste modo, reprímense e foméntanse na prensa determinadas actitudes e valores que se consideran socialmente axeitadas para cada sexo baixo unha estereotipación patriarcal, discriminatoria e opresora que é reflexo do proceso de socialización imperante, que responde tamén ao que se espera reproducir.

Cando se atende ao seo da familia rural é recorrente que aparezan tamén representadas figuras como a avoa ou o avó, que asumen significados roles na estrutura familiar; e alusións ao traballo no campo e no fogar, no que nenos e nenas participan. Fundamentalmente o neno preséntase colaborando no campo e no mar, mentres que a nena coopera nas tarefas domésticas; se ben é común que tamén aparezan imaxes de nenas participando nos traballos colectivos realizados no campo ou no mar, non se mostran imaxes de nenos interactuando nas tarefas do fogar.

\section{V) Maternidade loada: a muller como ser maternal.}

As imaxes que aparecen en Céltiga con respecto á figura materna son ben diferentes ás que se mostran en relación á paterna. A muller, loada pola súa condición como nai dedicada, é a persoa que atende ás demandas das crianzas. Os vínculos materno-filiais aparecen reflectidos tanto a través dos textos como das imaxes,

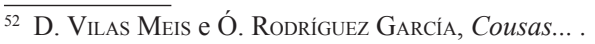


onde as mulleres de idade media practicamente sempre aparecen acompañadas de cativos. O reflexo do amor materno, así como as calidades agardadas para o futuro adulto (neste caso remitindo á construción da identidade de xénero masculina), pode observarse no seguinte fragmento:

Pepín es para su mamá el sol, la felicidad, la alegría. Ahora es muy pequeño $y$ su vida es pequeña, pero después se hará grande como un gigante. Tendrá una gran barba y unos grandes bigotes, y su vida será grande, clara, bella. Sera bueno, inteligente $y$ fuerte $^{53}$.

A exaltación da maternidade está ben presente, non só porque é o socialmente agardado para unha

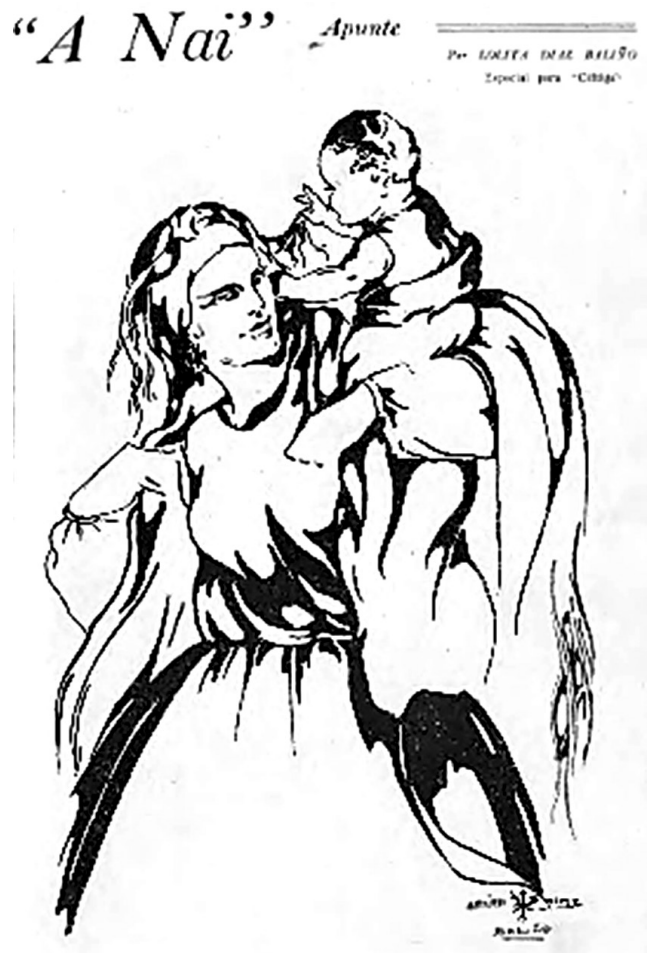

Fig. 9. A Nai. Apunte, por Lolita Díaz Baliño. En Céltiga, 25 de xullo de 1930, núms. 133-134, páx. 21. muller na sociedade tradicional patriarcal e debido aos intereses en clasificar a función social das mulleres como exclusivamente reprodutiva ${ }^{54}$, senón tamén porque é percibida como "fuente de vida" 55 , como garante da continuidade familiar e da mellora das condicións materiais no rural. Este enaltecemento da maternidade lígase en múltiples ocasións ao concepto "elevado de la suprema función social y fisiológica de la mujer"56.

Avógase, entón, por atender á "sublime e insustituíble función maternal"57 mediante o amparo á muller nai, porque se estima dese modo ir "reeducando a la mujer, quien un día, concluirá por comprender que su misión en la vida no es

\footnotetext{
${ }_{53}$ Páginas infantiles. El gigante, por Leonidas Andreies. En Céltiga, 11 (28 de xaneiro de 1925), páx. 33.

${ }^{54}$ Cynthia E. Russet, Sexual Science: The Victorian Construction of Womanhood, Cambridge, Harvard University Press, 1989.

${ }_{55}$ Céltiga, 7 (30 de decembro de 1924), páx. 6.

56 Por Pascual Troise. En Céltiga, 7 (30 de decembro de 1924), páx. 6.

57 Céltiga, 7 (30 de decembro de 1924), páx. 6.
} 


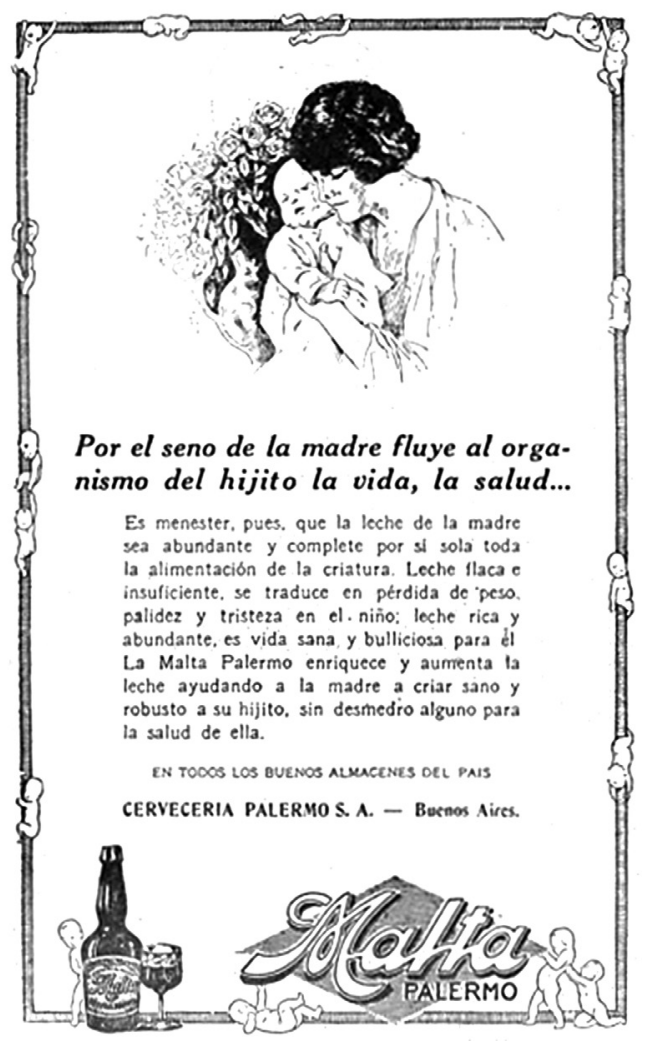

Fig. 10. Publicidade de Cervecería Palermo.

En Céltiga, 30 de decembro de 1924, núm. 7, páx. 34.

una simple cuestión de instinto librado a sus solicitaciones ancestrales" 58 . As afirmacións destas liñas, nas que coinciden outros autores, auspician a fundación de "Maternidades", onde "como principio, hallarían su salvación los hijos - problema social que interesa y afecta a la propia nacionalidad- y (tendría lugar) el comienzo de la educación de madres (para) todas las mujeres ignaras o infelices" ${ }^{\prime 59}$. É así que se procede reiterativamente en Céltiga ao enaltecemento da maternidade e da muller, precisamente para preservar deste xeito as funcións, roles e ámbitos que tradicionalmente lle asigna o patriarcado e a moral católica. Son tamén múltiples os textos nos que se recoñece a moralidade hexemónica do catolicismo que reprime as nocións ligadas á sexualidade feminina, delimitándoa a fins meramente reproductivos, ademais de perfilar o corpo das mulleres a mercede dos intereses masculinos e como obxecto de control por parte do poder androcéntrico.

As representacións da muller-nai aparecen tamén na publicidade, pois todos os anuncios relacionados con alimentación infantil, medicamentos ou incluso cervexa (ligada propagandisticamente ao aumento da lactancia materna) van dirixidos ás nais que "deseen criar a sus hijos sanos"

A nai tamén aparece retratada ante a emigración como muller loitadora e sufridora ante a despedida e espera dos homes e dos fillos, de xeito que a emigración é configurada como "traxedia das mulleres galegas":

\footnotetext{
$\overline{58}$ Por Pascual Troise, en Céltiga, 7 (30 de decembro de 1924), páx. 6.

${ }^{59}$ Por Pascual Troise, en Céltiga, 7 (30 de decembro de 1924), páx. 6.

${ }^{60}$ Céltiga, 10 (15 de febreiro de 1925), páx. 42.
} 
Tua probe nai-jou traxedia inmensa das mulleres galegas!-ainda reza todal'as noites por teu pai emigrado, e xa logo rezará tamén por ti a orazón angustiosa dos alonxados. Presinteo cando pol'as noites vixía o teu sono; un sono onde non hay fadas, nin princesas encantadas, nin enanos, como n'os sonos dos nenos da vila. No teu sono hay mares fabulosos, piñeirales inmensos desvaidos en brétema, n'o lonxán hourizonte ${ }^{61}$.

O perfil de nai que se exalta en Céltiga responde ao tópico da mater dolorosa, mater admirabilis que o catolicismo venera na figura das virxes cristiás, correspondente tamén co modelo arquetípico da "laboriosidade silenciosa" desexábel para as mulleres por parte do patriarcado, onde a abnegación, a humildade e a modestia se converten nas virtudes agardadas. Así, o papel feminino fica relegado a ser nai e viúva (de vivos e de mortos).

VI) Infancia emigrante e infancia que agarda o retorno da emigración, "e nais que non teñen fillos e fillos que non ten pais” (Pra Habana!, Rosalía de Castro).

Desde as páxinas de Céltiga proxéctase a defensa da dignidade dos emigrantes de orixe galega, loitando contra os posíbeis desprezos a emigrados. A emigración está presente nas representacións da vida dos nenos, en moitas ocasións porque é o futuro irrevocábel que se espera para eles; neste sentido aléntase a que non esquezan nunca a súa orixe:

¡Non esquenzerás, nón, as duas cousas santas de toda santidade, as duas deidades que teñen un altar en cada corazón galego: A Nai i-a Terra!

¡O conxuro d'eses dous grandes amores, trunfarás n'o mundo! Serás Poeta, ou Músico; serás Apóstol, ou Nauta. ;Serás o que queiras ser, a troques de que seas sempre galego, sólo galego! ${ }^{162}$

Mais a cuestión da emigración tamén aparece evocada no presente da vida dos pícaros, ben porque eles mesmos se ven inmersos neste proceso, ou ben porque o viven a través da migración dos seus familiares, particularmente, da figura paterna. A emigración é sentida desde a morriña e a saudade, pero a meirande das veces non se concibe en Céltiga como unha traxedia contra a que loitar, porque "iSoyo

\footnotetext{
${ }_{61}$ Por Suárez Picallo. En Céltiga, 22 (25 de novembro de 1925), páx. 11.

${ }^{62}$ Por Suárez Picallo. En Céltiga, 22 (25 de novembro de 1925), páx. 11.
} 
traballo lle piden á América! E América, xenerosa e noble, darálles traballo, Libertade e Amor a presas cheas. Pol-as xélidas e soberbas costas patagónicas; pol-a inmensidade verde das Pampas arxentinas; pol-o Chaco abraxado do Sol tropical e pol-as ruas da grande cibdade arxentina, esparéxese un novo anaco da i-alma galega, aterecida de door e de saudade. ¡Deus a guíe!’63.

Mentres tanto, "no probe fogar mariñeiro queda a nai tolleita, e dous irmanciños agardando pol-o que él gane en América como pol-o Santo advenimento. C'os brazos cruzados i-os cabelos ao aar, mira ó mar con fonda xenreira. Emporeso de noite soña e oiselle decir: 'Couce’, ‘Asimán’, 'Orza’, ‘¡Duro de babor!'. ¡Soña qu’e peixeiro na Costa Fisterrán!’’64.

\section{VII) Pobreza e abandono infantil como problemas a resolver.}

Os asuntos ligados á pobreza infantil aparecen en Céltiga-expresados maioritariamente a través de crónicas, artigos de opinión e da narrativa- recoñecidos como problemáticas que superar por unha cuestión de xustiza social, en harmonía cos principios ilustrados de igualdade e fraternidade. Deste modo, recoñécense as necesidades que viven "os nenos pobres" como eivas no marco legal bonaerense, que non atende aos dereitos que garantirían a protección da infancia, se ben a caridade segue a ter certo protagonismo como reclamo particularmente nos meses que envolven as datas máis próximas ao Nadal. O texto que segue pode resultar ilustrativo do que vimos sinalando:

Ha empezado el mes con una simpática nota: la del día de los niños pobres. Pero nosotros quisiéramos para todos los niños del universo, no un día: la vida entera de los adultos del presente consagrada a ellos. Bueno es atacar el mal producido. Mejor es evitar que se produzca. La caridad, dentro de la organización actual, resulta plausible. Sin embargo, sobre tal sentimiento y sobre tal acción, hállanse el sentimiento y la acción de la solidaridad humana. Bastaría recordar y practicar la doctrina de Jesús: Amaos los unos a los otros. ;Los niños pobres! En vez de socorros-generosos, indudablemente-preferiríamos leyes que garantizasen a la infancia sus alimentos, sus ropas, sus calzados ${ }^{65}$.

A realidade do abandono infantil está presente nas páxinas de Céltiga sobre todo a través das expresións literarias (contos ou poemas), nas que se ve reflectido

\footnotetext{
${ }^{63}$ Céltiga, 45 (10 de novembro de 1926), páx. 17.

${ }^{64}$ Céltiga, 45 (10 de novembro de 1926), páx. 17.

${ }^{65}$ Por Luis de Neda. En Céltiga, 2 (12 de outubro de 1924), páx. 4.
} 
o achádego de crianzas abandonadas por parte de adultos, como pode apreciarse no seguinte fragmento: "n-us farrapos envolto, ¡meu neniño!, unha vella topouno n-un camiño"66, que aparece novamente en números posteriores e acompañado de imaxe como parte do texto íntegro de Noriega Varela traducido ${ }^{67}$.

Nos textos que remiten á cuestión da infancia desvalida (ben sexa por aludir á pobreza ou ao abandono) a carga afectiva e sentimental adoita ser moi elevada, introducindo termos que denotan pertenza e suscitan tenrura, presentando ademais os substantivos en diminutivo (por exemplo: "meu neniño", "os nosos pícaros", "cativiño", entre outros). A infancia represéntase, neste caso, como vítima inocente das inxustizas sociais obxecto de denuncia.

\section{VIII) Importancia da educación moral e da escola como factores de progreso.}

Poden observarse na revista Céltiga múltiples textos que elaboran críticas da escola presente (prescrita, real e vivida ${ }^{68}$ ) acompañados dos esbozos dunha escola que é reivindicada como necesidade para o "progreso social" e o "desenvolvemento cultural". Nas páxinas da revista ilustrada ponse en valor a importancia dunha "educación moral" que procure "espertar a humanidade" das persoas; non obstante, a medida que avanzan os números, percíbese unha meirande focalización na idea de educación para o futuro da "Suprema Patria Galega", ligada fundamentalmente ao (auto)coñecemento da contorna máis próxima, a cal fica representada no rural.

Tamén son atendidas cuestións ligadas á educación, á que se lle outorga un papel crucial para formar aos futuros adultos. Asúmese, pois, que a educación moral é importante ao entender que "la moral es la base de la familia, la unión de la sociedad, el bienestar de los pueblos. La educación moral concierne a la voluntad y a la forma de someterla a las reglas del deber. La supremacía de esta potencia entre todas las humanas manifiesta la de esta educación sobre la del cuerpo y la del entendimiento"69.

A importancia outorgada ás conexións entre a familia e a escola aparece reflectida sobre todo nos primeiros números, onde se interpreta que a escola debe "ser la prolongación del hogar gallego, y el hogar, la prolongación de la escuela"70, por este motivo, "el aula, como el hogar, es una fragua a la que no debe faltar jamás el fuego", como escribe Carmen Sonda de Pandolfini ${ }^{71}$. Neste escenario, o mestre constitúe un actor clave que debe saber guiar e graduar as aprendizaxes,

\footnotetext{
${ }_{66}$ Céltiga, 10 (15 de febreiro de 1925), páx. 38; frase a pé.

${ }^{67}$ Céltiga, 31 (10 de abril de 1926), páx. 5.

68 Antonio Viñao Frago, "Escolarización, edificios...".

${ }^{69}$ Apuntes Pedagógicos, por José Guixé. En Céltiga, 13 (10 de xullo de 1925), páx. 32.

${ }^{70}$ Por Ángela Ana Abasolo. En Céltiga, 8 (15 de xaneiro de 1924), páx. 34

${ }^{71}$ Páginas infantiles, por Carmen S. de Pandolfini. En Céltiga, 7 (30 de decembro de 1924), páx. 12.
} 
asumindo un rol para o que é preciso "no ser ni pródigo ni avaro (pues) el tino es la mejor balanza en la cual debe medirse para obtener las obras artísticas y hasta perfectas" $" 72$.

Son múltiples as críticas que se presentan en Céltiga con respecto á escola existente, aos seus espazos e recursos, sobre todo atendendo a aqueles centros situados no rural galego que non responden ás expectativas e necesidades do alumnado:

Las escuelas rurales, además de no ser suficientes en número, en comparación a los niños que debieran recibir educación en ellas, no cuentan con el material de enseñanza necesario ni con locales adecuados, tal como lo exigen las leyes y reglamentos que se refieren a la materia. Las autoridades superiores tampoco demuestran mayor interés en cumplir lo que a sus deberes corresponde y es así que los inspectores no realizan las visitas que son de obligación a esos establecimientos en donde se deben cultivar las virtudes y el carácter del niño y formalmente la inteligencia de los futuros ciudadanos de la Nación ${ }^{73}$.

Existen tamén variados e extensos textos nos que se critica a ausencia de escolas, reivindicando a necesidade da súa presenza para "loitar contra o analfabetismo", contribuír á "elevación del nivel cultural del pueblo"74 e encamiñar a "nazón galega" cara o progreso. Por todo isto, son valoradas con eloxios as achegas efectuadas desde a Galiza emigrante que, con todo non están exentas de críticas.

Entre os recursos do centro escolar, o que máis se valora en Céltiga é o espazo exterior do centro, pois configúrase como o entorno máis importante para a ensinanza de determinadas aprendizaxes, tales como as ligadas á Agricultura ${ }^{75}$, pois esta:

tomada únicamente en el aula, no conduce a ningún fin práctico, pues sólo queda reducida a la contemplación de los diferentes cuadros gráficos que se utilizan para estos casos, y a aprender una multitud de nombres que pasado algún tiempo acaban por olvidarse; pero si esos conocimientos teóricos son aplicados en

\footnotetext{
72 Páginas infantiles, por Carmen S. de Pandolfini. En Céltiga, 7 (30 de decembro de 1924), páx. 12.

73 Céltiga, 15 (10 de agosto de 1925), páx. 14.

${ }^{74}$ Céltiga, 42 (25 de setembro de 1926), páx. 21.

75 Obsérvase en Céltiga que en es menester de la escuela "ocuparse de la enseñanza de la Agricultura en la niñez”. Apuntes Pedagógicos, por José Guixé. En Céltiga, 14 (25 de xullo de 1925), páx. 39.
} 
la práctica, y la escuela pudiese contar con un campo en donde el niño desarrollase dicha enseñanza, entonces ésta sería perfecta, contribuyendo al mismo tiempo a su desarrollo fisico, a despertar en el pequeño agricultor el amor hacia esta ciencia ${ }^{76}$.

Hai lugar en Céltiga para atender a iniciativas que son indicio "tanto da presenza actuante do espírito da Escola Nova en Galiza como do nacemento dun proxecto pedagóxico ligado ao proxecto dunha nova sociedade galega" ${ }^{\text {"77; }}$; é o caso da atención prestada ao movemento galego de colonias infantís, como reflicte o amplo artigo recollido na revista que responde ao título Una institución admirable. Las colonias escolares del Rebullón. Neste artigo destácase como a colonia escolar de Rebullón (en Mos, a nove quilómetros de Vigo) contaba cun "espléndido" edificio construído a proposta do vogal da Comisión de Colonias da Caja de Ahorros Emilio Martínez Garrido, para albergar así a colonia escolar permanente. Do edificio, destacaba Leonardo de la Peña en Céltiga:

un magnifico, alegre y muy limpio comedor, con veinticinco mesas de a cuatro plazas cada una (...). Luego, una buena cocina, blanca, limpia, bien ordenada y sin moscas, y con una gigantesca cocinera que estoy seguro desarrollará todas sus espléndidas energías en cocinar bien para los niños (...). Y allí todo en orden, todo blanco, sin una rotura ni un desconchado, sin un letrero en las paredes, iadmirable! ${ }^{78}$.

\section{CONCLUSIÓNS}

Nas revistas culturais ilustradas galegas Vida Gallega (Vigo) e Céltiga (Bos Aires) poden apreciarse representacións da infancia que, aínda converxendo en determinados aspectos, diverxen en consonancia cos diferentes imaxinarios do presente e do futuro social que se bosquexan nestes voceiros dunha e doutra marxe do océano. Cada unha das revistas analizadas posúe entidade propia, defínese por unhas específicas características, sitúase nun marco espazo-temporal concreto e, aínda, nela escriben diversos suxeitos cuns determinados valores, ideoloxías e visións do mundo (condicionados e/ou influenciados tamén polas respectivas circunstancias estruturais).

\footnotetext{
${ }_{76}$ Apuntes Pedagógicos, por José Guixé. En Céltiga, 14 (25 de xullo de 1925), páx. 39.

77 Antón Costa Rico, Escolas e mestres. A educación en Galicia da Restauración á II República, Santiago de Compostela, Servicio de Publicacións da Xunta de Galicia, 1989, páx. 305.

${ }^{78}$ Una institución admirable. Las colonias escolares del Rebullón, por Leonardo de la Peña. En Céltiga, 164 (25 de outubro de 1931), páxs. 13-14.
} 
Baixo todos os tópicos que reflectimos para cada análise individual, subxacen ideas ligadas á infancia no ámbito familiar, á infancia abandonada e marxinada, á saúde da infancia, á escolarización infantil, ao traballo infantil e á emigración e a infancia. En todos estes eixos están presentes de forma transversal a identidade de clase social, a identidade de xénero e a identidade nacional.

É en Céltiga onde a perspectiva sociolóxico-política da infancia e da súa educación adquire máis notábel peso, pois nas súas páxinas aparece constantemente a idea da infancia como "semente do porvir galego" sendo, polo tanto, nos nenos (maioritariamente) e nas nenas, en quen se depositan as esperanzas dos cambios socio-políticos que poden garantir un futuro mellor. A educación, necesariamente vinculada ás contornas de orixe, compréndese na revista bonaerense como chave para posibilitar o progreso ansiado e, a escola, como o espazo preciso para "loitar contra o analfabetismo".

Porén, na revista Vida Gallega prevalece unha ollada da infancia de carácter tradicional antropolóxico-relixiosa. O considerábel protagonismo da escola e da educación escolar no medio vigués, onde a educación é concibida como un acto de "perfeccionamento" e "modelado", fai fincapé nunha idea de suxeito infantil pasivo e dependente, necesitado dunha educación imposta e desenvolvida nos "centros de progreso" (escolas) mediante unha aprendizaxe formal e intelectualista na que a memorística adquire o peso preponderante. En todo caso, convén destacar que os anhelos de progreso, de modernidade e de "distinción social", atravesados polos ideais cívico-burgueses de urbanidade e de consumo son comúns aos medios analizados.

\section{BibLIOGRAFÍA}

Alonso, Luis, Abal, Élida e Cillero, Alexandra, Céltiga (1924-1932). Revista Gallega de Arte, Crítica, Literatura y Actualidades, Xunta de Galicia, Secretaría Xeral de Política Lingüística, Centro Ramón Piñeiro para a Investigación en Humanidades, 2009.

Beramendi, Justo, De provincia a nación. Historia do galeguismo político, Vigo, Xerais, 2007.

Blanco, Carmen, "Mulleres na utopía celta de Pondal", en Unión libre: Cadernos de vida e culturas, vol. 2, 1997, páxs. 101-118.

Bolaño Amigo, María Eugenia, “Os nenos en Castelao”, en Gran Enciclopedia Galega, A Coruña, Novos Vieiros, 2015, tomo 49, páxs. 166-173.

Costa Rico, Antón e Bolaño Amigo, María Eugenia, "Castelao: nenos, sociedade e educación. Denuncia e patria soñada na Galiza dos anos vinte", en Imatges de l'escola. Imatge de l'Educació. Actes de les XXI Jornades d'Història de l'Educació, Palma de Mallorca, Universitat de les Illes Balears, 2014, tomo 49, páxs. 297-311.

Costa Rico, Antón, Escolas e mestres. A educación en Galicia da Restauración á II República, Santiago de Compostela, Servicio de Publicacións da Xunta de Galicia, 1989, páx. 305. 
González Bello, Rosa María, “A revista Vida Gallega: unha visión da emigración galega a América (1909-1938)", en Actas do V Congreso Internacional de Estudos Galegos, Sada, Ediciós do Castro, 1999, páxs. 353-363.

Miguélez-Carballeira, Helena, Galiza, um povo sentimental? Género, política e cultura no imaginário nacional galego, Santiago de Compostela, Associaçom Galega da Língua, 2014, páx. 20.

Molina Sánchez, César Antonio, Prensa literaria en Galicia (1809-1920), Vigo, Xerais, 1989.

Neira Vilas, Xosé, A prensa galega en Cuba, Sada, Ediciós do Castro, 1985.

Pulpeiro, Sylvia e Rodríguez, Pablo (eds.), Eliseo Pulpeiro. As letras galegas entre dúas ribeiras (Ribadeo e Río da Prata), Santiago de Compostela, Consello da Cultura Galega, 2016, páx. 9.

Ribao Fernández, Roberto, A fotografia na revista Vida Gallega: un silandeiro universo de sentido, Universidade de Santiago de Compostela, Servizo de Publicacións e Intercambio Científico, 2007.

Russet, Cynthia, Sexual Science: The Victorian Construction of Womanhood, Cambridge, Harvard University Press, 1989.

Sorensen, Janet, The Grammar of Empire in Eighteenth-Century British Writing, Cambridge, Cambridge University Press, 2000.

Valcárcel, Marcos, cit. en Henrique Alvarellos, Un século de Vida Gallega, a revista literaria máis popular, dispoñíbel en http://www.aelg.org/resources/centrodoc/members/paratexts/ pdfs/autor317/PT_paratext5188.pdf_[Consulta: 20/10/2017].

Vilas Meis, Diana e Rodríguez García, Óscar, Cousas de nenos. Unha aproximación á representación da infancia en Cousas da vida de Castelao, Pontevedra, Deputación de Pontevedra, 2014, páx. 44.

Viñao Frago, Antonio, "Escolarización, edificios y espacios escolares", CEE. Participación Educativa, vol. 7, 2008, páxs. 16-27. 